\title{
The Second Phase of the Trypillia Mega-Site Methodological Revolution: A New Research Agenda
}

\section{John Chapman ${ }^{1}$, Mikhail Yu Videiko ${ }^{2}$, Duncan Hale ${ }^{1}$, Bisserka Gaydarska ${ }^{1}$, Natalia Burdo ${ }^{2}$, Knut Rassmann ${ }^{3}$, Carsten Mischia ${ }^{4}$, Johannes Müller ${ }^{4}$, Aleksey Korvin-Piotrovskiy ${ }^{2}$ and Volodymyr Kruts ${ }^{2}$}

${ }^{1}$ Department of Archaeology, Durham University, UK

${ }^{2}$ Institute of Archaeology, Ukraine

${ }^{3}$ Romano-German Commission, Germany

${ }^{4}$ Institute of Prehistory, Christian-Albrechts University, Germany

The first phase of the Trypillia mega-sites' methodological revolution began in 1971 with aerial photography, magnetic prospection, and archaeological excavations of huge settlements of hundreds of hectares belonging to the Trypillia culture in Ukraine. Since 2009, we have created a second phase of the methodological revolution in studies of Trypillia mega-sites, which has provided more significant advances in our understanding of these large sites than any other single research development in the last three decades, thanks partly to the participation of joint Ukrainian-foreign teams. In this paper, we outline the main aspects of the second phase, using examples from the Anglo-Ukrainian project Early urbanism in prehistoric Europe: the case of the Trypillia mega-sites', working at Nebelivka (also spelled 'Nebilivka'), and the Ukrainian-German project 'Economy, demography and social space of Trypillia mega-sites', working at Taljanky ('Talianki'), Maydanetske ('Maydanetskoe'), and Dobrovody, as well as the smaller site at Apolianka.

Keywords: mega-site, Trypillia, archaeological method, settlement, houses

\section{INTRODUCTION}

The fundamental archaeological approach to the origins of urbanism was developed by Childe (1928), who combined evolution with diffusionism in his view that prehistoric European social complexity was secondary to that of the Near East. While pristine urbanism in regions other than Western Asia has been accepted for the Far East, Egypt, Meso- and South America (Claessen \& van der Velde,
1991), the current and widespread view is that the earliest towns in Europe date to the Aegean Bronze Age in the late third and second millennia $\mathrm{BC}$ - the towns of the Minoans and Myceneans. This view has consistently ignored the development of Trypillia sites in Eastern Europe, the largest of which are as large as the Early Bronze period I city of Uruk (Mesopotamia). It is particularly curious that Trypillia mega-sites have been so persistently overlooked despite Fletcher's (1995: 
198-200) observation, almost twenty years ago, that they were the only global exceptions to his agrarian settlement limits, or even despite Narr's (1975: 212-28) integration of them into his handbook of prehistoric archaeology. After all, the mega-sites date to the Trypillia BII-CI phases (c. 4000-3200 BC).

Although Ukrainian archaeologists have used the provocative term 'proto-urban' for the mega-sites (Shmaglij et al., 1973; Videiko, 2004), there has been a sceptical response to this claim by many other prehistorians, who observe the lack of impressive public buildings and obvious wealth differentials (e.g. Masson, 1980; Zbenovich, 1989; Monah, 2003; Kruts et al., 2005; cf. reply by Videiko, 2007).

It is clear that the Trypillia phenomenon is such an unusual development that it merits a fresh assessment in the context of wider Eurasian prehistoric trends towards urbanism. In this article, we outline the most dramatic methodological breakthrough in Trypillia studies in its four decades of research (Videiko, 2012). The second phase of the so-called 'Trypillia methodological revolution' provides many new opportunities to understand the phenomenon of the mega-sites. It is the aim of this article to summarize the new data and discuss its potential for advancing our understanding of these large but still misunderstood settlements.

\section{RESEARCH BACKGROUND}

The Trypillia-Cucuteni culture of Ukraine, Moldova, and North East Romania (5000-2700 BC) has been termed 'the last great Chalcolithic civilization of Europe' (Mantu et al., 1997) - a late flowering of 'Old Europe' at a time when settled village life, advances in gold and copper metallurgy and vivid and varied material culture had come to an end a millennium or more earlier in most other regions of South East Europe (Figure 1). Although Gordon Childe introduced Trypillia (as 'Tripolye') to mainstream Anglophone archaeology in the 1920s (Childe, 1928), the publication of most site monographs and articles in local languages has limited knowledge and the impact of Trypillian discoveries to a small group of specialists. Moreover, there has been a lack of interest in areas on the periphery of Gimbutas' (1974) 'Old Europe'. This has led to the neglect of the most striking aspect of Trypillian practices-the development of a series of mega-sites, covering 200-340 ha, which are the largest sites in 4th millennium Europe and as large as the Early Bronze Age city of Uruk (Mesopotamia). The sheer size of these 'mega-sites' not only prompts questions of the complexity of social structure(s) necessary to sustain such settlements, and the logistics and long-term planning needed to provision them, but also makes them very hard to investigate.

This review of past research begins with methodological considerations, before moving on to the social interpretations of the mega-sites and the research response from the late 2000s. Since 1971, in the first phase of the methodological revolution, mega-sites have been studied using three methods. Remote sensing (aerial photographs and magnetometry) has given an impression of settlement plans, although without much detail (Shishkin, 1973; Shmaglij et al., 1973). Archaeological excavations have provided information about the structure and architecture of the buildings and settlements, as well as good data for the internal chronology of the mega-sites based on pottery typology (Ryzhov, 1990; Shmaglij \& Videiko, 1990). However, after several decades of excavation, Ukrainian colleagues are currently unable to sequence the houses on a single mega-site by scientific dating, 


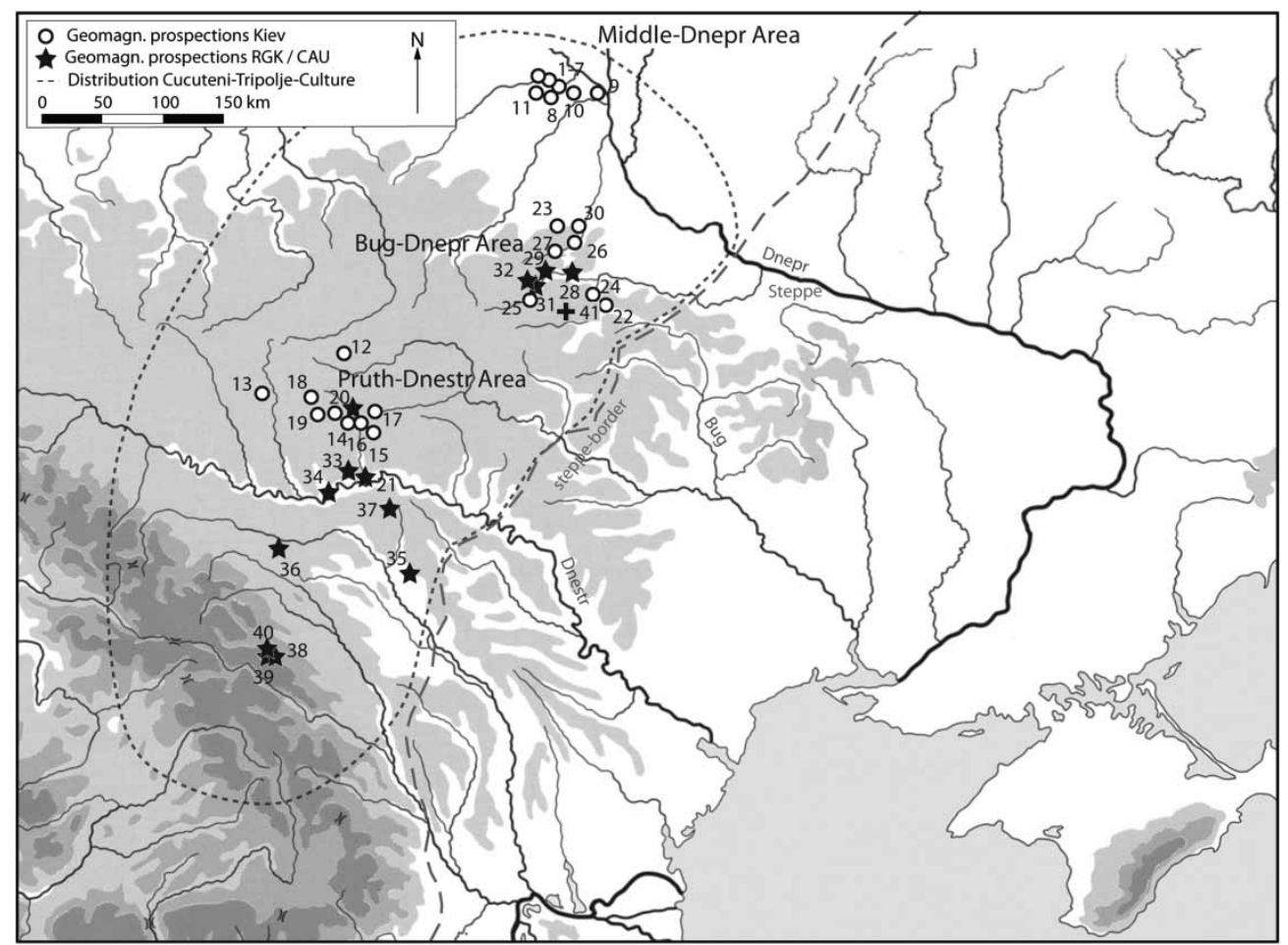

Figure 1. Location map of Trypillia-Cucuteni groups, with key-sites prospected by Ukrainian researchers and the Frankfurt/Kiel team: 1-7, Stajky (ur. Charkove), Vasylynsyn Jar (Grebeny), Vynogradnoe (Grebeny), Janča 1 + 2; Popovka Levada; 8, Kurjače Polé (Jušky); 9, Grygoryvka (ur.Chatyšce); 10, Ř̌ijšcev (Chomyne); 11, Jujšky (ur. Žuravka); 12, Konovka (Ukraina); 13, Brinzeny Ostrov; 14, Trifanesty; 15, Putinesty; 16, Ivanovka; 17, Starye Raduljani II; 18, Glavan 1; 19, Glavan (Sofja 2a); 20, Lamojna 1; 21, Petreni; 22, Mogyĺna 3; 23, Glybočok; 24, Fedorovka (Mychajlovka); 25, Yatranivka (Jatranovka); 26, Jampol; 27, Mošurov 1 (early); 27, Mošurov 1 (late); 28, Maydanetske; 29, Taljanky; 30, Oĺkbovets; 31, Apolianka; 32, Dobrovody; 33, Ochiul Alb; 34, Koban; 35, Horodka; 36, Ruginoasa; 37, Singereni; 38, Poduri; 39, Prohezesti; 40, Rapa Morii; 41, Nebelivka.

despite recent attempts using radiocarbon dates from Taljanky (Rassamakin \& Menotti, 2011), Vesely Kut, or all megasites (Rassamakin, 2012; Videiko, 2013: 115-28). The difficulties of creating radiocarbon-based internal microchronologies may, however, be more related to choice of samples rather than the method itself. These problems can be limiting for a precise reconstruction of the population size at any given phase of the site occupation (while the total size of the settlement gives broad indications for house numbers and population size, such information needs further precision, not least due to varying building density) and hinders attempts to elucidate the sequence of mega-site growth, floruit, and collapse. Although they do enable us to approximate the dimensions of population size, the new robust settlement maps resulting from our recent geomagnetic prospection clearly cannot yet be used for precise demographic modelling. However, we can currently neither place mega-sites in a micro-regional or regional settlement context nor understand their human impact on the forest steppe landscape. 
In terms of social interpretations of these massive sites, they were initially not perceived as anything out of the ordinary, although there were claims that they may show a transition from village to town (Petrov, 1992). Later, the mega-sites were viewed as inter-tribal centres, based on a fraternal (sic!) relationship (Bibikov, 1965). The most prolific interpretation in recent years has been the hypothesis of proto-towns/proto-cities (Shmaglij et al., 1973), acting as centres of chiefdoms or complex chiefdoms (Videiko, 1990). However, other Ukrainian colleagues dwell mainly on their size in terms of demography (population estimates), certain economic aspects, resisting the term 'urbanism' in favour of 'farming villages' (Kruts et al., 2001; Kruts, 2012). In the 1970s-1980s, the mega-sites were placed in a broader social context through their inclusion in Gimbutas' (1974) concept of 'Old European civilisation'. The significance of Trypillia mega-sites on a global scale was first observed by Roland Fletcher in his insightful book The Limits of Settlement Growth. Fletcher (1995) identified the Trypillia mega-sites as the sole exception to his global model of constraints on agricultural settlement expansion. In particular, Fletcher identified two behavioural limits in the structuring of sedentary farming sites-the interaction limit and the communication limit. If the interaction-limit of 300-600 people per hectare was exceeded, there would have been problems with population density and crowding; if the communication-limit of 100 ha was exceeded, it would have been hard for all or most of the people to keep in touch with each other for all or most of the time (Fletcher, 1995: 19899). Interestingly, Fletcher observed the absence of cultural and spatial factors mitigating these two limits, whether internal settlement divisions for the former or a written language for the latter. On the basis of the early remote sensing plans, Fletcher (1995) found that the Trypillia mega-sites were the only global exceptions to these two limits.

Our response to these research issues was the creation of international interdisciplinary research projects, one jointly organized by Durham University (Chapman) and the Kyiv Institute of Archaeology (Videiko), the other, a large-scale prospection project in Ukraine and Moldova, initiated by the RomanoGermanic Commission (Rassmann) in cooperation with the Kyiv Institute of Archaeology (Videiko, Burdo, Kruts, Korvin-Piotrovskiy) and ChristianAlbrechts University, Kiel (Müller). The research strategy thereby employed (focussing on three different spatial levels - site, micro-region and macro-region) provides a platform for the integration and interpretation of much fresh data which has a high potential for answering the three crucial issues raised by Trypillia mega-sites: what are the details of a wellsequenced mega-site? How was the provisioning of such large sites managed across the landscape? And can we detect a trajectory towards local, European urbanism? (Chapman, 2014; Müller, 2014).

The heart of the second phase of the methodological revolution is a new approach made possible by advances in geophysics. These devices were originally designed for the detection of unexploded ordnance, and had been used for more than three decades in archaeological fieldwork, normally on the scale ranging from some hundred square meters up to a dozen hectares. The last years of technical evolution led to the construction of multi-sensor-gradiometers, which allow moving the size of the surveyed area on a totally different scale. A pilot study on the Early Bronze Age settlement of Fidvár near Vráble in southwest Slovakia (20082012), with a surveyed area of more than 
180 ha, demonstrated the potential of these gradiometer systems for the detection of archaeological features over large areas (Batóra et al., 2012). During the 2009 summer field season at the mega-site of Nebelivka, Kirovograd Domain, the creation of a 15 ha-plot, led to the identification of all of the major, and well-known, features of a mega-site plan but in much greater detail than before, as well as a number of new features (Hale et al., 2010). The extension of this geophysical investigation in summer 2012 produced a detailed 65-ha plan-about one third of the size of the mega-site of Nebelivka.

The Frankfurt-Kiel team started their research on Cucuteni-Trypillia sites in Moldova in 2009. Obtained by means of a 5 -sensor gradiometer mounted on a manpowered chassis, their results confirmed the presence of the significant burnt house structures as detected decades earlier by Dudkin (1978). Building upon this experience and in order to evaluate its potential for use on a Copper Age site, small-scale prospection was completed on sites in Moldova (Petreni, Ochiul Alb, and Horodka: Rassmann et al., in press). In the following years, large-scale investigations continued at Petreni, where the entirety of its 36 ha surface was examined (Rassmann et al., in press). Thanks to ideal ground and weather conditions in Ukraine in 2011 and 2012, around 400 ha were prospected (191 ha at Taljanky; 151 ha at Maydanetske; 23 ha at Dobrovody; and 38 ha at Apolianka: Rassmann et al., in press). Even at such large sizes, prospecting covered only approximately 6070 per cent of the areas in Taljanky and Maydanetske. In Dobrovody, only the Northern part of the settlement was examined as crops covered the rest of the settlement area. In addition, nearly one quarter of the Neolithic site is presently covered by a modern village. Naturally, one must consider the fact that smaller settlements existed as well as the megasites. The first geomagnetic data concerning this (smaller) kind of site was obtained from Apolianka (20 ha), which revealed settlement features which are very similar to those from Nebelivka.

The comparison of the data from both teams clearly illustrates the structural similarities which existed between settlements of the Trypillia Culture. The net result of these fieldwork initiatives has been the largest increase in basic mega-site fieldwork information in the 40-year history of their investigations (Burdo et al., 2012; Kruts et al., 2012; Videiko, 2012, 2013). This constitutes the second phase of the methodological revolution in Trypillia mega-site studies: the successful application of advanced gradiometers to produce detailed site plans, whose features have been checked by systematic excavation.

\section{What's Old? What's New?}

\section{What's old?}

The earlier remote-sensing programmes for the investigation of the Trypillia megasites have defined the overall parameters of the study, constituting the first Trypillia mega-site methodological revolution (Shishkin, 1973, 1985; Shmaglij et al., 1973; Dudkin, 1978; Shmaglij, 1980). Even the extraordinary Star Wars' image of Taljanky (Dudkin, 1978; here Figure 2A) made well-informed archaeologists such as Ellis (1984) recognize the signs of an emergent and little understood phenomenon. But the weird lines and cross-hatching on the aerial photograph of Taljanky were borne out in greater detail in the next phase of aerial photography, which revealed that some of the lines were rows of parallel houses stretched out across the sites (henceforth termed 'circuits'). 

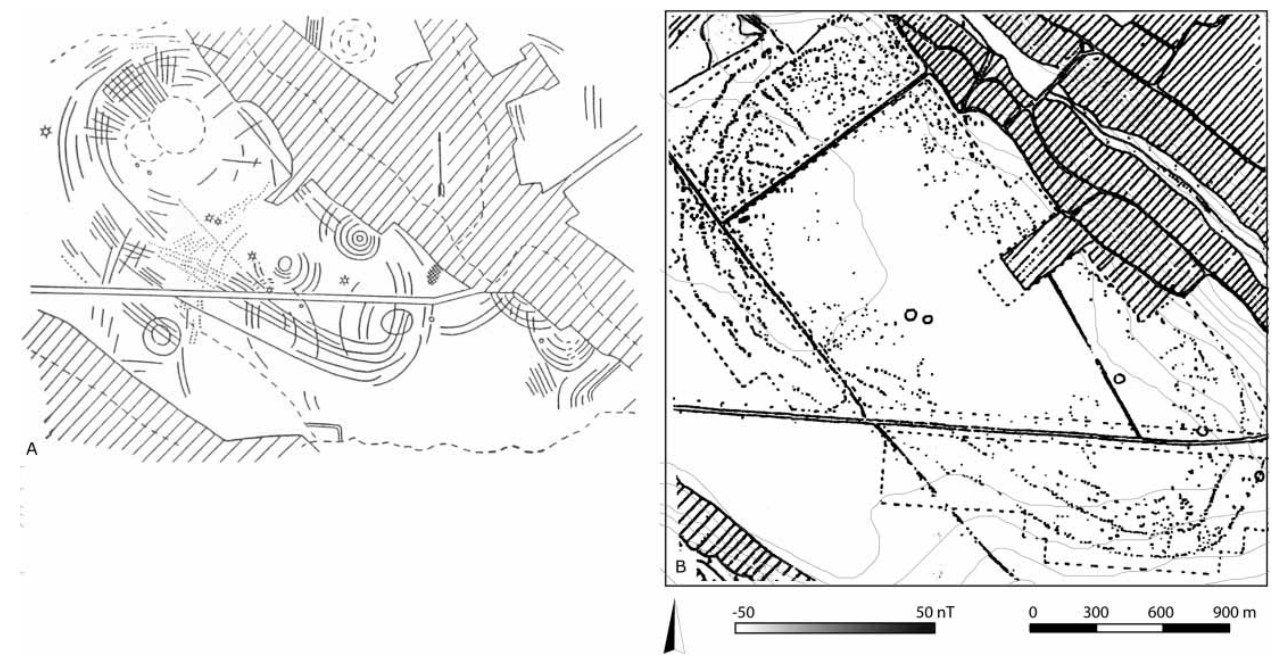

Figure 2. Taljanky. (A) Interpretation of an early geophysical plot/aerial photograph of Taljanky; (B) later interpretation of geophysical survey.

Sources: (A) Dudkin (1978); (B) Shmaglij \& Videiko (1987)

Ground-truthing by a pre-computerized version of gradiometry (Shmaglij \& Videiko, 1987; here Figure 2B) demonstrated that the aerial images represented magnetic anomalies which, when excavated, turned out to be massive deposits of burnt daub-the so-called Trypillia 'ploschadki' of traditional Russian excavation literature (Passek, 1940; cf. Childe, 1945; Bibikov, 1965). The apogee of these early geomagnetic surveys was a set of plots for seven mega-sites completed in the 1970s to 1990s by Dudkin, covering a total area of nearly 800 ha (Dudkin \& Videiko, 1998, 2004). The astonishing dimensions of the first truly large-scale geomagnetic prospections in Europe were based on an innovative research design that took into account the size of burnt houses. The aim of Dudkin and colleagues' prospection was rapid detection of house structures rather than obtaining a conventional high-resolution gradiometric map. Dudkin's team realized this goal by geomagnetic measurements in a $4 \mathrm{~m} \times 4 \mathrm{~m}$, later $2 \mathrm{~m} \times 2 \mathrm{~m}$, grid.
In Taljanky, this method detected nearly 80 per cent of the houses that were present. This methodology was strikingly precise in that it first defined the archaeological question and then structured the method of answering those questions. Thus, the early remote sensing and geomagnetic prospection programmes, in tandem with trial excavation, achieved four aims: (1) the confirmation that these sites were indeed far larger than any coeval site in the rest of Europe; (2) the demonstration that the mega-sites were indeed a genuine phenomenon and not simply the result of unusual atmospheric or ground conditions; (3) the dating of the houses in the mega-sites, and hence the mega-sites themselves, to the Trypillia period; and (4) the confirmation that several mega-sites shared common elements of planning, as constituted by the five principal elements of spatial layout.

The five principles on which the layout of the mega-sites was based comprised: (1) at least two, and possibly as many as four, principal concentric circuits of structures; 
(2) an open space in the centre of the site, inside the inner circuit; (3) an open space between the two circuits, constituting a buffer zone of varying widths; (4) the construction of some structures inside the inner circuit, infringing the inner unbuilt space to a greater or lesser extent and with greater or lesser attachment to formal planning; and (5) the construction of some structures outside the outer circuit, also with greater or lesser attachment to an organized layout. The relatively coarsegrained remote sensing data underlying these principles restricted the unit of analysis to the settlement plan, with detailed consideration of individual houses from excavation.

In terms of formal planning of the mega-sites, these five principles were defined in the first two decades of research. Arguably the clearest example of this genre was the plan of the larger than 132 ha settlement of Glybochok (also spelled 'Glubochek') (Dudkin \& Videiko, 2004; here, Figure 3). In the light of the funding issues that held back mega-site research in the transition to post-Soviet Ukrainian and Moldovan society, there were neither serious challenges to, nor expansions of, these planning principles during the late 1990s and most of the 2000s.

\section{What's new?}

The initial mega-site breakthrough since 2009 resulted from the large-scale use of modern gradiometer-systems of different designs. In the southern end of the Nebelivka mega-site, a team of two geophysicists (Richard Villis and Nat Swann) covered 15 ha with a Bartington Grad 601-2 two-sensor gradiometer in a two-week period. At Taljanky, Maydanetske, Dobrovody, and Petreni, the German/Ukrainian/Moldovian project employed with similar success a different, newly designed geomagnetic instrument: a SENSYS MAGNETO ${ }^{\circledR}$-MX ARCHsystem (SensysGmbh, Bad Saarow, Germany) (Rassmann et al., in press). This system consisted of sixteen gradiometer-sensors mounted at $0.25 \mathrm{~cm}$ intervals on a vehicle-drawn cart. This is towed at speeds of $8-12 \mathrm{~km} / \mathrm{h}$ with a sample rate of twenty readings per second. The set-up provides co-ordinate data on a mesh of $0.25 \mathrm{~m}$ by approximately $0.1 \mathrm{~m}$. In combination with an integral Trimble-GPS system, the team had access to real-time locational data with an accuracy of $\pm 4 \mathrm{~cm}$, with a surveyed area reaching up to 30 ha per day.

Independent of the technical equipment used by the two teams, the resulting plans were impressively detailed (i.e. Nebelivka North part, Figures 4 and 5), provoking a personal comment from one author (M. Yu. Videiko) that 'the plans of the anomalies resemble excavation plans'. These results created two new units of analysis for mega-site studies: from now on, not only was it possible to study the entire settlement plan through magnetic gradiometer survey but there was the opportunity to consider both individual structures and groupings of structures.

We shall consider the 2009 results from Nebelivka in tandem with those from its 2012 season (when a further 55 ha were covered in a five-week prospection using two Bartington gradiometers; Figures 4 and 5), referencing results obtained by the German-Ukrainian team at Taljanky, Majdanetskoe, and Dobrovody as appropriate. The geophysical documentation of complete sites confirms observations made on parts of other sites.

\section{Individual features}

In Dudkin's previous large-scale prospection, the majority of house anomalies was 


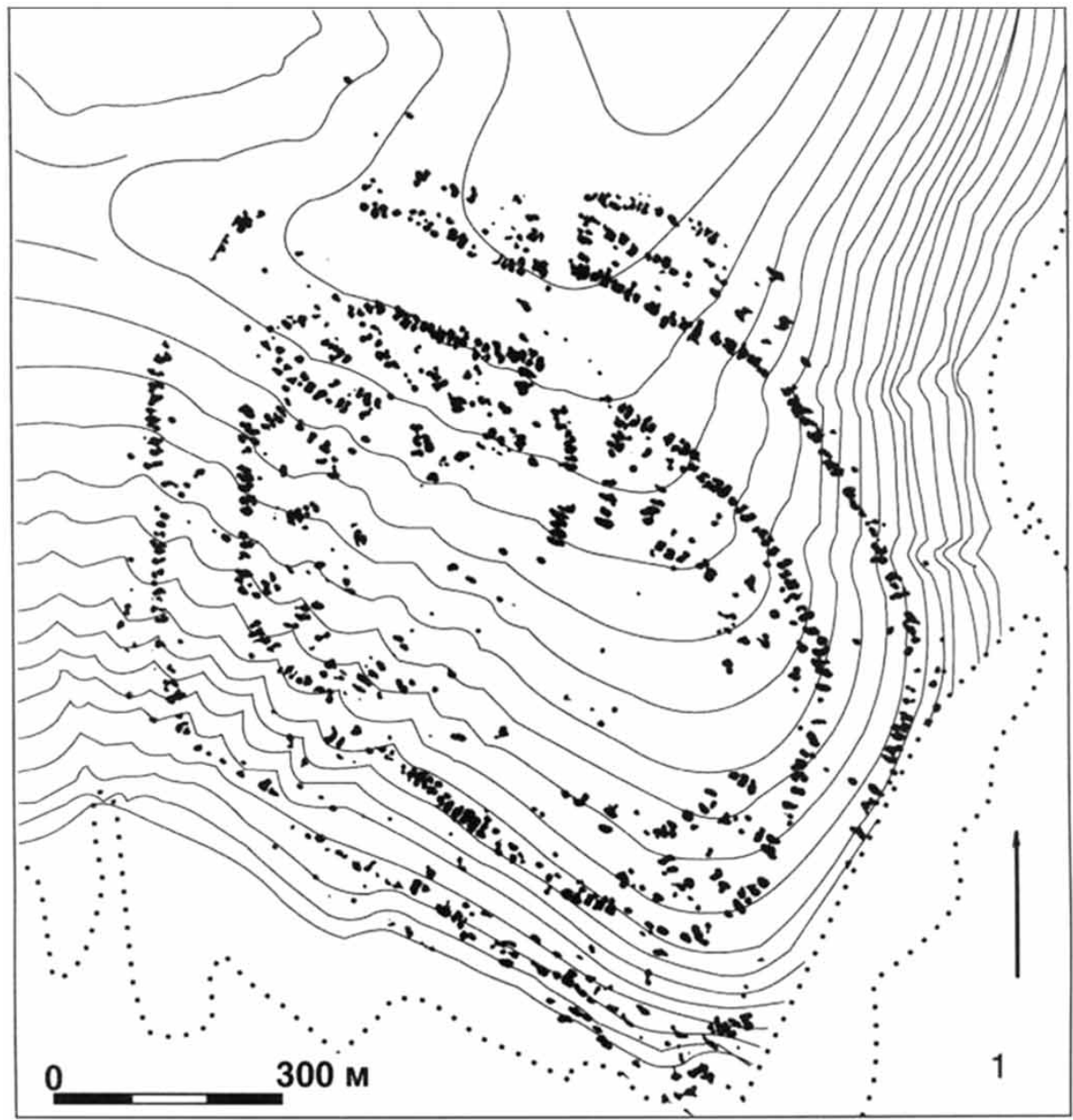

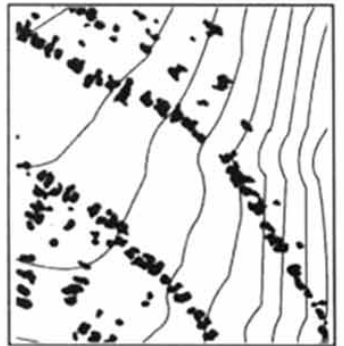

(a)

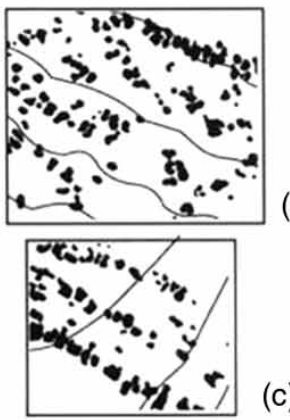

(b)

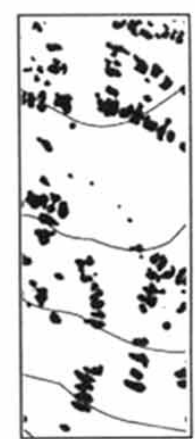

(d)

Figure 3. Glybochok. Geophysical plot of the mega-site. Source: Dudkin \& Videiko (2004)

discovered and the general structure of the individual structures lacked clarity (e.g. settlements was found. However, signs of Maydanetske: Shmaglij \& Videiko, 2002- 


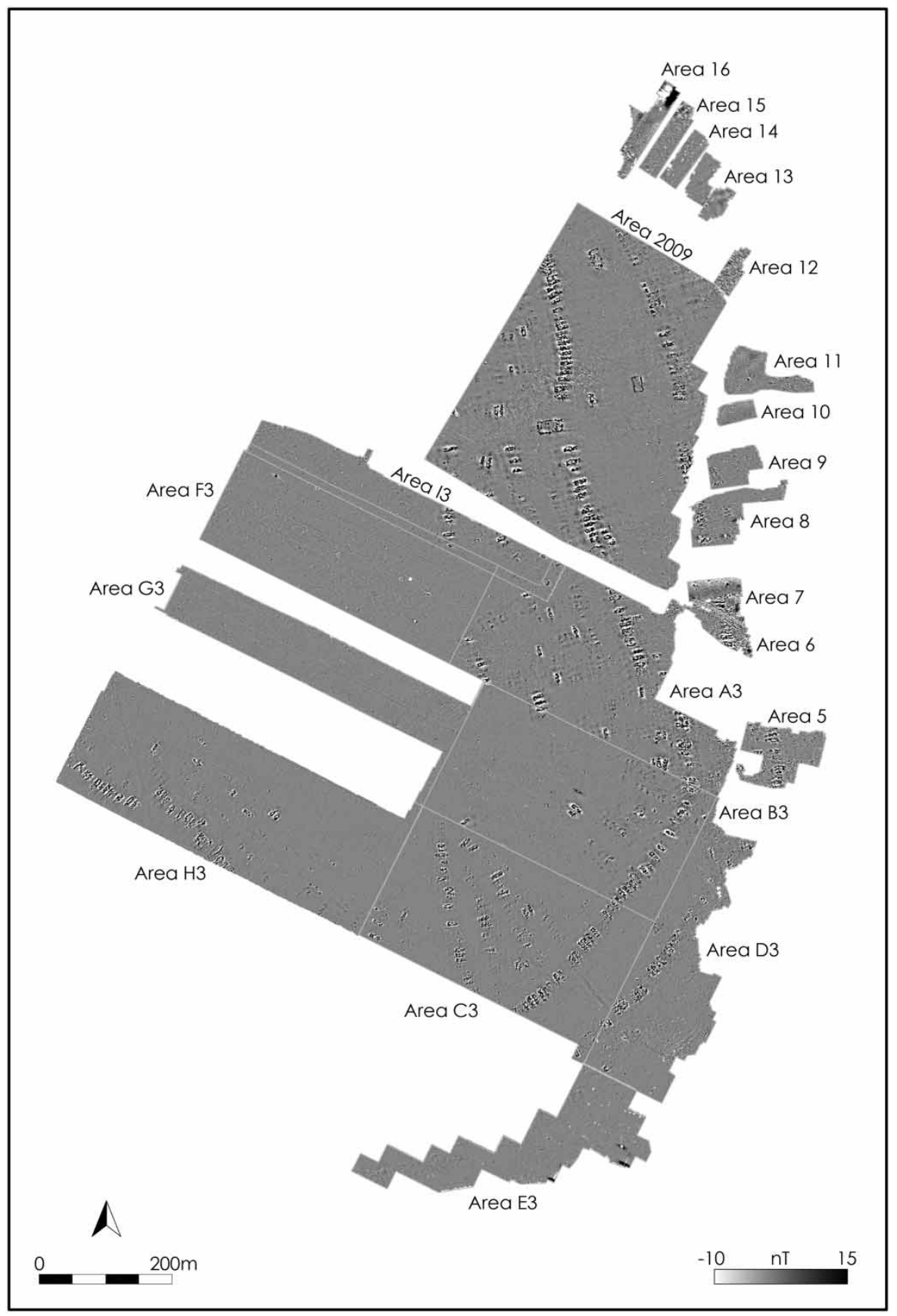

Figure 4. Nebelivka. Grey-scale plot of mega-site (2009 and 2012).

Source: D. Hale, Archaeological Services

3). With the new plans, it became possible structures more accurately. It was also to specify the dimensions of individual possible to separate those parts of 


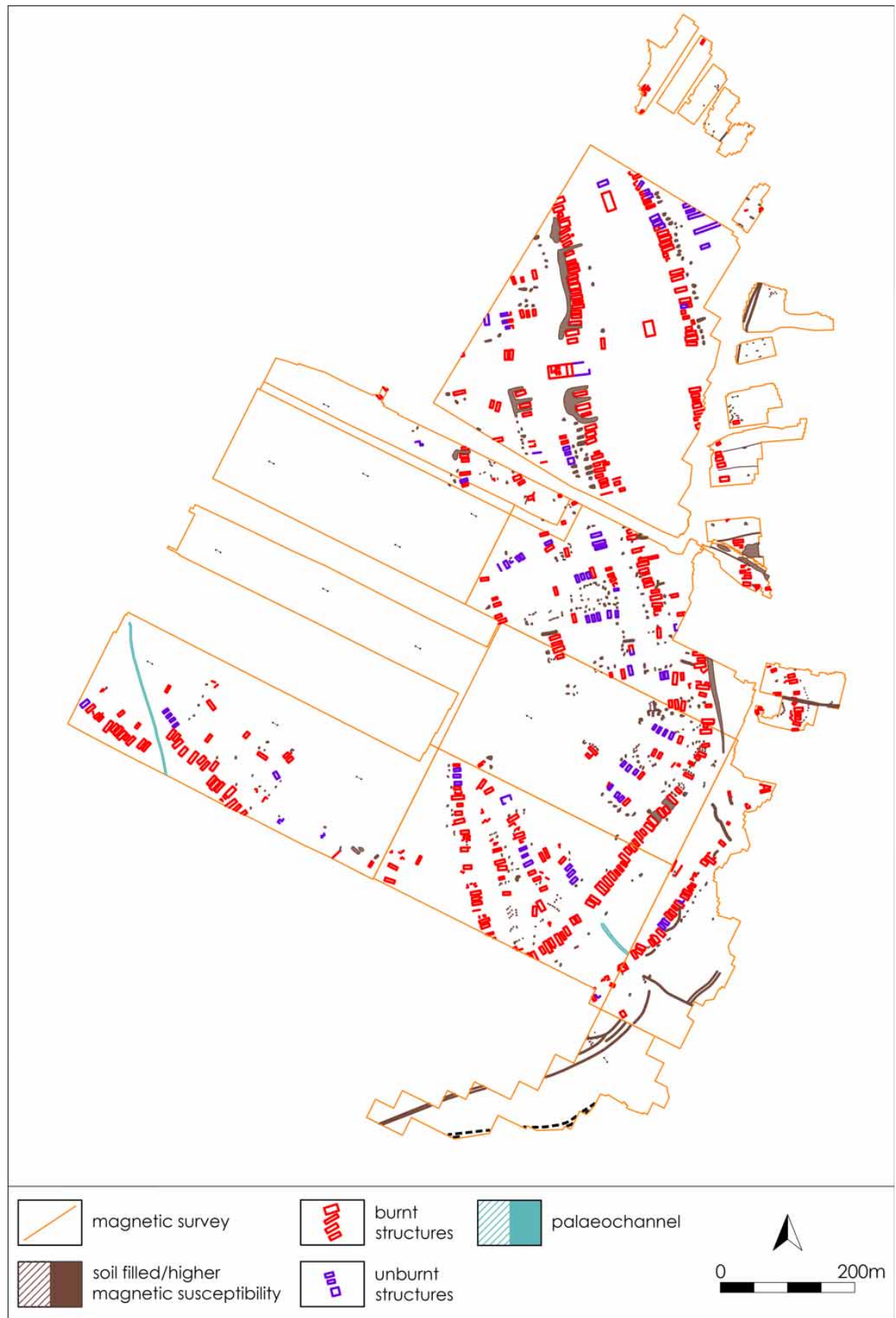

Figure 5. Nebelivka. Interpretative plot of mega-site (2009 and 2012).

Source: D. Hale, Archaeological Services

structures with stronger anomalies (i.e. 20-60 nT) from those with anomalies of burnt parts, with a broad range of values, lower strength (i.e. unburnt or less 
strongly burnt, with values of 1-2 nT). An example was the very large structure located in the gap in the main inner line of houses at Nebelivka (2009 survey) (Figure 5).

An even more significant discovery was the identification of new types of feature. The first new type of structure was the unburnt house. There was a clear distinction between structures defined by strong anomalies (i.e. burnt houses) and structures of similar size and shape with much weaker anomalies (Figure 6). The latter have been interpreted as unburnt or weakly burnt houses-none of which have been recognized in the Trypillia research programme of over a century because of the absence of detailed geophysical plans. The vast majority of individual houses in the main circuits were burnt at the time of their abandonment. This was also the case in the longer house lines inside the inner circuit (Nebelivka Area C3; Taljanky Area D). However, there was a consistent dominance of unburnt over burnt houses in the short house lines in Nebelivka Area B3, Taljanky Area A, Maydanetske Area A and many of the house ensembles in Nebelivka Areas A3, as well as the 2009 survey area at Nebelivka. The excavation of unburnt houses on Trypillia sites will need pursuing if we are to understand the relationships between burnt and unburnt houses in the future.

The second new element identified in geophysical investigations was the pit-a circular or oval negative anomaly (Figure 6). Probing in the areas of such anomalies in 2009 at Nebelivka produced a total absence of burnt daub and a dark, highly organic fill-both features consistent with a pit. The excavation of pits is common in excavations of Cucuteni sites (e.g. Hăbăşeşti: Dumitrescu et al., 1954; Traian: Dumitrescu, 1957; Drăguşeni: Marinescu-Bîlcu, 2000), as well as on some Trypillia mega-sites (e.g.
Majdanetskoe: Shmaglij \& Videiko, 2002-2003). There is considerable variation in the size of the pit-like anomalies at these sites. At Nebelivka, they range from the small anomalies in Area 5 to the long rectangular pit-like anomalies found in the 2009 Area, for example (Figure 6). One additional but rare feature concerns the discovery of a house-sized negative anomaly apparently showing the features of pit fill (Figure 8: Area B3). This raises the possibility of a burnt structure filled with midden material from a nearby pit.

The third and potentially most interesting new discovery concerned the size of a small number of magnetic anomalies. Three of the four north-south circuits at Nebelivka were interrupted by a gap with the same orientation, one of which (Row B) was located in the largest structure (B5) yet to be found on any Trypillia site (Figure 6). This structure was bipartite, with burnt walls covering near $38 \mathrm{~m}$ in length and $20 \mathrm{~m}$ in width, and an enclosed area of the same width and over $20 \mathrm{~m}$ in length. Two other larger-than-usual buildings were also located at the same site, both located between the main circuits (Figure 5 and Online Supplementary Material 1). The term used for such buildings was the 'mega-structure'-the first signs of architectural differentiation by size on any mega-site.

The fourth new discovery was the identification of ditch structures at different sites (Nebelivka, Taljanky, Maydanetske). Interestingly, yet another new feature made apparent by the magnetometry included sets of internal ditches which have mostly been located outside the outer circuits of these mega-sites. The precise dating of these ditches (and thus their relationship to the mega-sites themselves) remains unclear, prompting future test excavations. However, three spatial patterns have emerged for the ditches. First, there are several ditches that respect 


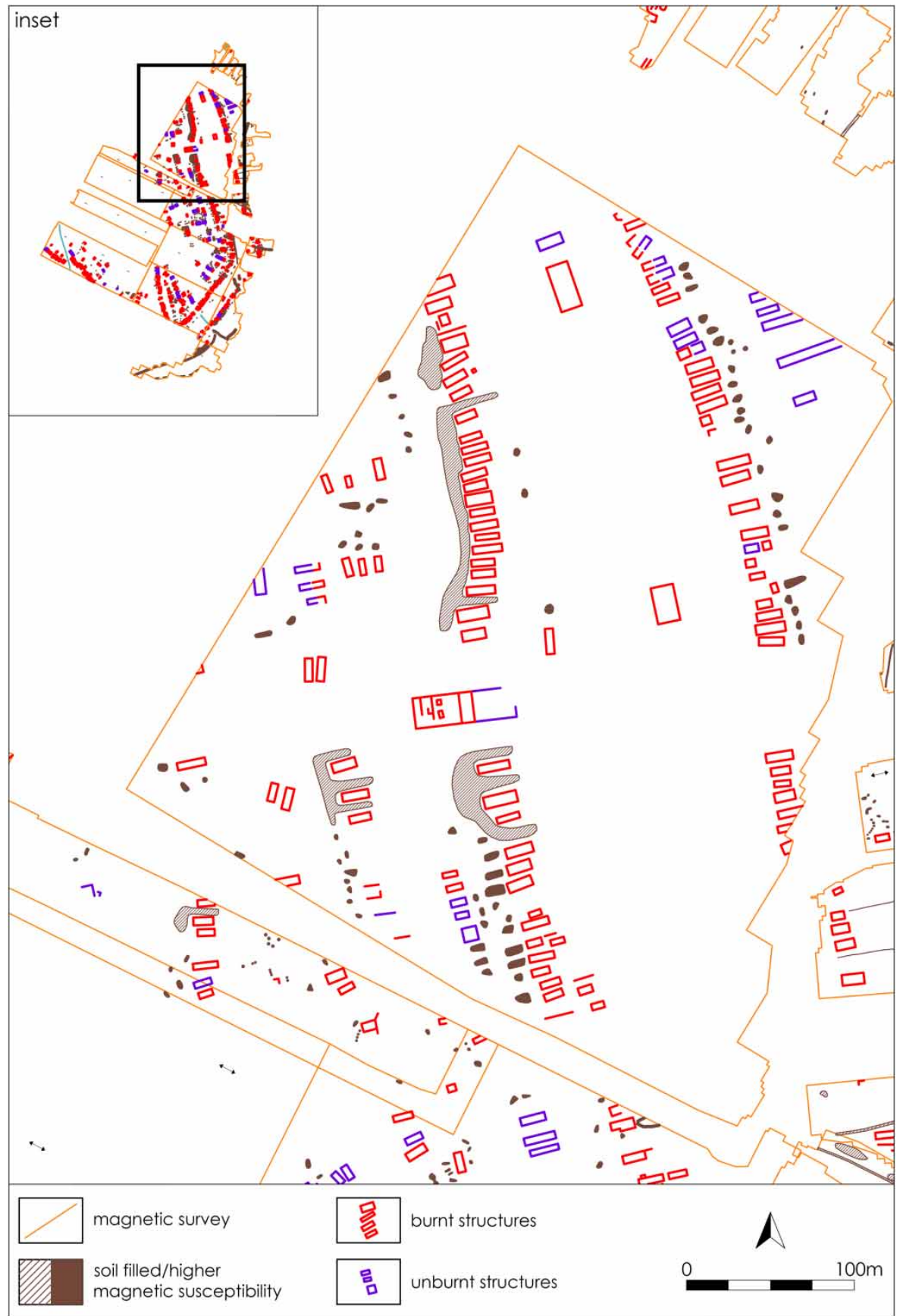

Figure 6. Nebelivka. Magnetic anomalies in the 2009 Area.

Source: D. Hale, Archaeological Services 


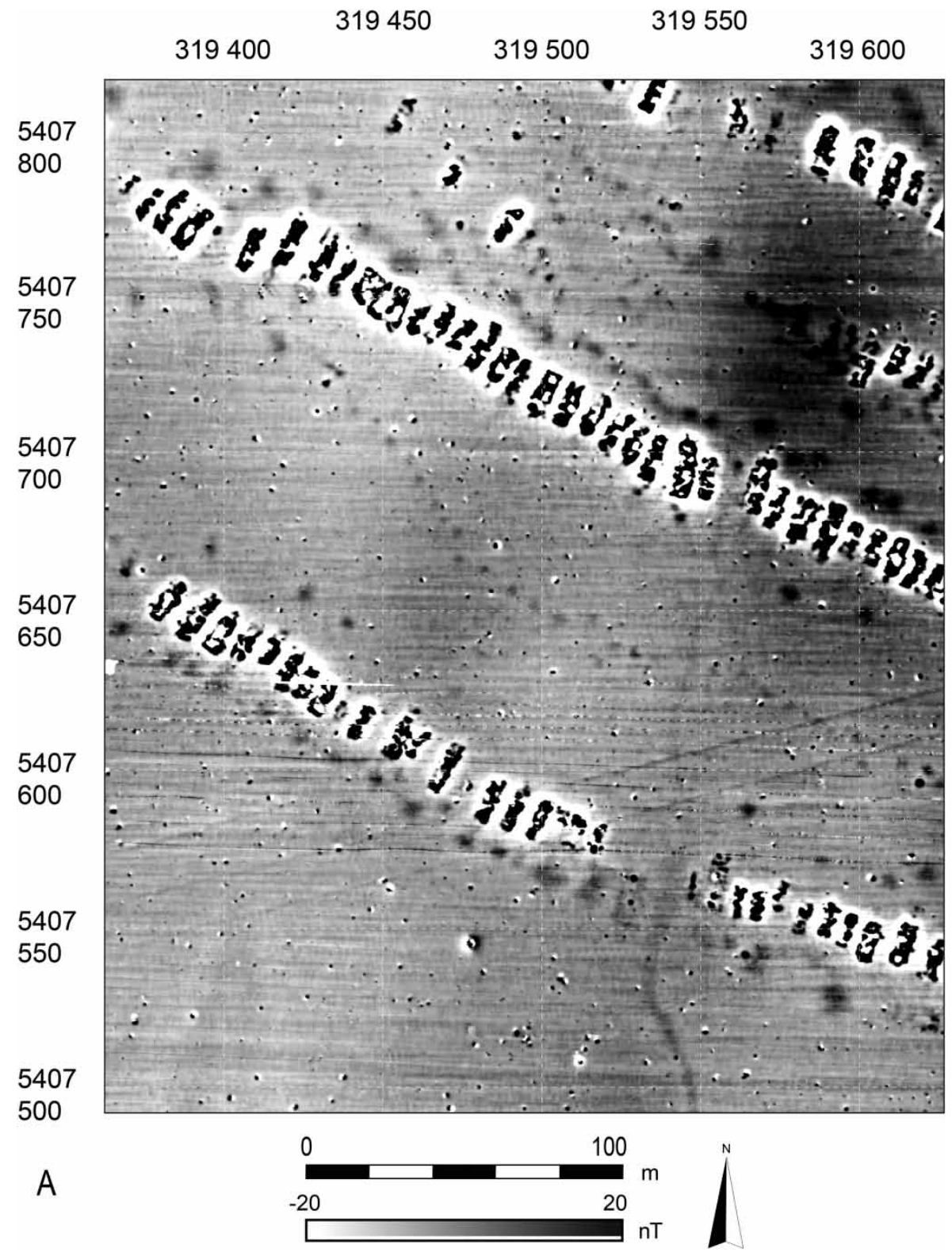

Figure 7. Taljanky: magnetic anomalies interpreted as trackways.

Source: K. Rassmann \& C. Mischka

the outer circuit and echo its concentric alignment (e.g. ditches in Nebelivka Area D3-E3, D3, B3, and A3-B3; Online Supplementary Material 2, southern part; Taljanky Area A and C, Maydanetske). While the longer ditch in Nebelivka Areas
D3-E3 was cut outside the outer circuit, the shorter ditch in Areas A3-B3 was dug between the two main circuits, running very close to the houses in A3. In the southern and western part of Maydanetske, the ditch follows the outermost 


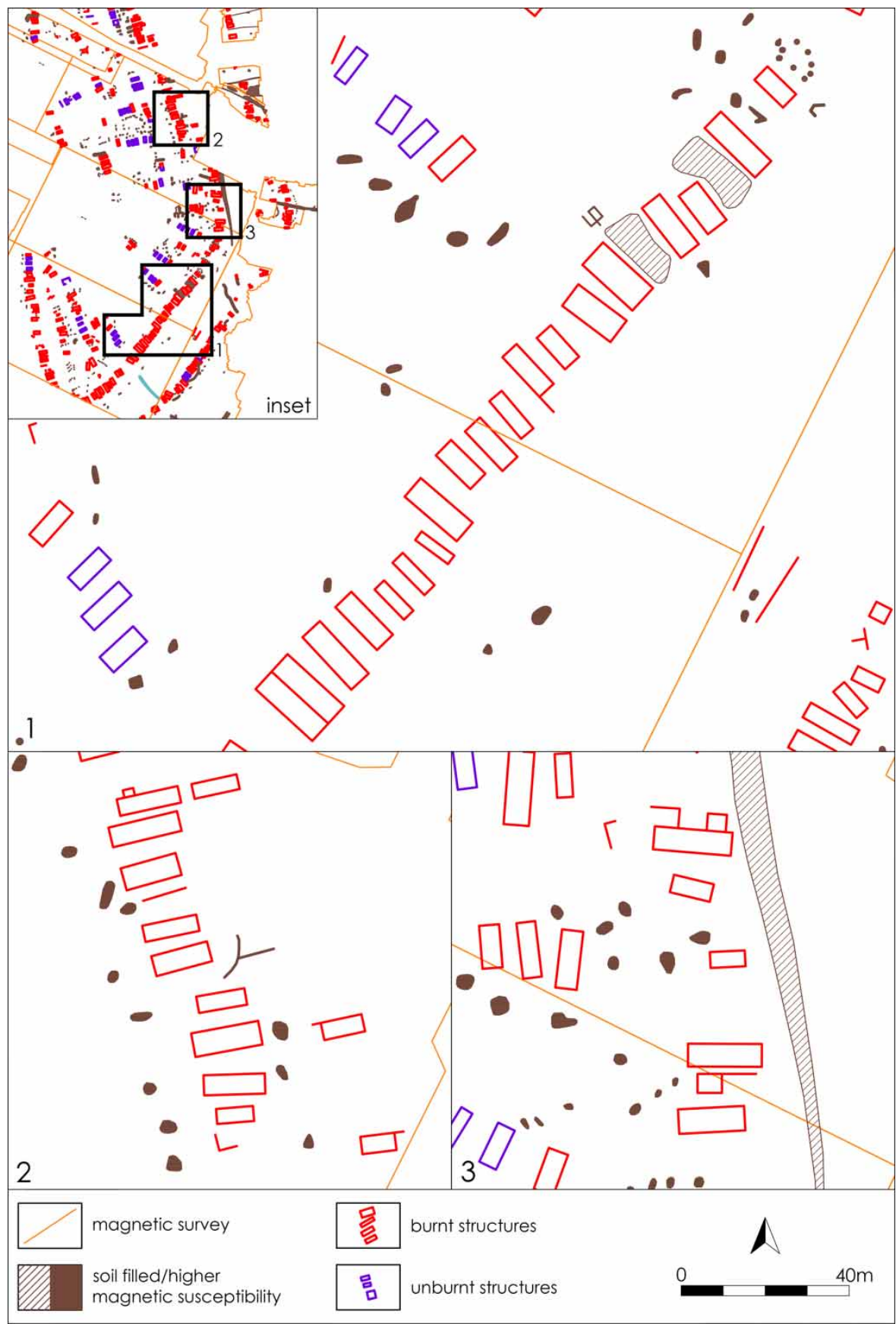

Figure 8. Nebelivka. House groupings in the inner circuit: 1, Area B3-C3; 2, Area A3; 3, Area A3-B3; hatched lines within house-midden inside house.

Source: D. Hale, Archaeological Services

circle of houses for approximately $25 \mathrm{~m}$. In circles lie outside the ditch, perhaps pointthe northeast sector, at least two more ing to internal settlement evolution. 
The second pattern concerns generally shorter ditches that run approximately at right angles to the circuits, down the slope in the manner of possible drainage ditches (Areas D3, 5, 7, 8 and perhaps 13: Online Supplementary Material 2, northern part). The Area D3 ditch appears to mark the ends of one stretch of the long E3 ditch, and a shorter D3 double ditch. By contrast, the Area 5 ditch appears to cut a pit line and possibly even a burnt house. The third pattern includes ditches whose alignment is not closely related to the main circuits (e.g. Areas D3 (two), 6 and Areas 10-11: Online Supplementary Material 1). The single short D3 ditch abuts one part of the bifurcating B3 ditch, while cutting the other part. The Area 6 ditch appears to cut through a gap in the outer circuit, while abutting two large pit-like areas. At least two interpretative possibilities remain: first, we have early signs of a field system at Nebelivka, and, secondly, some of the 'ditches' may be associated with early tracks or roads out of the mega-site, as has been proposed for Maydanetske (Burdo et al., 2012).

The fifth new discovery was the geomagnetic identification of circular anomalies first identified as probable kilns in the 2012 geophysical investigation, confirmed in the 2012 excavations at Taljanky. This is the first time in which kilns have been identified in mega-sites in Ukraine. The much higher magnetic anomaly amplitude differentiated these anomalies from pit-shaped anomalies.

The sixth new discovery was the detection of trackways within the settlement, clearly visible at Taljanky. With these pathways, which are visible on the geomagnetic plan, house rows and house groups are connected with the outside world and internally (Figure 7).

Nearly all of the gaps in the main circuits in the Southern part of Taljanky were crossed by linear anomalies which were sinuous rather than straight. These lines probably mark old pathways, which could were likely to have been unpaved or surfaced, given the small magnetic anomaly amplitude of only 3-4 nT.

These magnetic anomalies were joined at Nebelivka by the presence of a palaeochannel that was not only detectable in the geophysical investigation but was also a landscape feature. Two such palaeochannels have been located so far at Nebelivka-a longer feature some $30 \mathrm{~m}$ in width (Area H3 - the western example), which runs into a modern stream, and a shorter channel (Area C3-the southern example) whose continuation beyond the outer circuit is marked by a possible ditch (Area D3; Figures 4 and 5). The western palaeo-channel is particularly interesting because it forced the Trypillia builders to change the line of the outer circuit, strongly suggesting that the palaeochannel pre-dated the occupation of this part of the mega-site (see below and Figure 17). Coring of the fill of this palaeo-channel encountered highly fragmented Trypillia ceramic (both daub and pottery) at $1.5 \mathrm{~m}$ depth. Examination of the locations of Taljanky, Maydanetske, and Dobrovody shows a similar association with nearby water sources that have since dried up. Interestingly, there are some indications that this particularity was echoed at the smaller site at Apolianka, leading us to relate the potential role of these landscape features to the location or even initial founding of such settlements.

The final new feature located concerns a mixed category somewhat intermediate between ditches and pits. In three cases in the 2009 Area at Nebelivka, as well as at Taljanky, Maydanetske, and Dobrovody, pit-like anomalies were extended to form linear anomalies (Online Supplementary Material 3). Each example abutted houses, partially enclosing them with an E-shaped linear pit form. The excavation of one 
such linear anomaly in 2013 at Nebelivka showed that one part was indeed a linear pit, while another part was a surface deposit. It is possible that the so-called 'ditch' in Areas A3-B3 at Nebelivka was another example of a linear pit, since the feature expanded at the Northern end to a width of approximately $4 \mathrm{~m}$. Both the southeast and southwest examples stopped at the end of a line of pits, suggesting complementary functions of spatial division. There can be little doubt of a general association between burnt houses and linear pits in at least one part of the mega-site, whatever their precise chronological relationship. While these novel features are of great individual interest to those researching Trypillia mega-sites, they also stimulate new approaches to the study of their spatial context in overall settlement planning. It is at this point that we turn to the novel combinations of individual features defined above.

\section{Feature combinations}

In the earlier phase of remote-sensing, mega-site planning was defined by the principal features of the circuits. The new plots by and large confirm these circuits but provide much more detail on three aspects - their regularity, the grouping of houses, and the nature of the gaps in the circuits.

The regularity of the circuits can be assessed in terms of their deviation from geometric order, their concentricity and the distance between them. There are two obvious re-alignments in the inner circuit-one in Area A3 at Nebelivka in a flat part of the site with no obvious topographical constraints, and the re-alignment in Area $\mathrm{H} 3$ that takes the pre-existing palaeo-channel into account (Figures 4 and 5). Otherwise, the inner circuit deviates from an oval shape for most of its course known so far, consisting of gentle arcs of houses (the 2009 Area), relatively flat, straight lines of houses (Areas 2009 and B3-D3), and a relatively steep turn at the southeast corner (Area A3). At Nebelivka, the course of the outer circuit is not, as yet, well known but there are such marked deviations in width between the two main circuits-from as little as $70 \mathrm{~m}$ to as much as $150 \mathrm{~m}$-that it is hard to maintain the principle of concentricity for more than 30 per cent of the circuits as known today (Figures 4 and 5). These findings suggest that while there is a planning principle that the house-builders at Nebelivka were aware of and followed as best they could, their final result was an approximation to the notion of oval concentricity. This may, in turn, relate to the length of time between the construction of segments of the two circuits.

In their earlier assessment of the spatial structure of the Maydanetske houses, clusters of houses that were built at the same time were identified because they were structurally linked with common walls (Videiko, 1990; Shmaglij \& Videiko, 2002-3; cf. the 'homesteads' at Vesely Kut: Tsvek, 2004). This architectural conclusion led to interpretation of kinship groups in house clusters as an important social principle for mega-sites. The new geophysical investigations extend our perspectives on the idea of the 'house cluster' still further by offering us great detail on the groupings. The outer circuit at Nebelivka, for example, reveals several single houses, several pairs of houses, some trios and groupings as large as eleven and eighteen parallel houses with minimal gaps between the structures (in the 2009 Area and Area C3-D3, respectively: Online Supplementary Material 4). The inner circuit shows no less variation, with no fewer than twelve house 'groups' of three or fewer members and house groups of up to twenty-three houses (Areas B3-C3) (Figure 8). Even at Maydanetske and Taljanky, a similar high 
variablility in house-groups is visible through the new settlement plans.

The gaps between house groups also indicate many potential choices for the separation of houses or groups from 'neighbours'. While many of the gaps hardly exceed the width of a typical Trypillia house by more than a factor of three, major gaps in both circuits in the 2009 Area at Nebelivka reached as much as $60 \mathrm{~m}$, providing an east-west alignment and the space to create one of the three mega-structures. Gaps between houses were also regularly reinforced with additional features, whether ditches (Area D3), linear pits (the 2009 Area), or lines of pits (Area B3). Such gaps are echoed in the layouts uncovered at Taljanky, Maydanetske, and Dobrovody as well, suggesting that the question of the meaning of the gaps between house groups requires further investigation, despite the fact that there is as much variability in this area as in other aspects of the mega-structure spatial organization. This variability in building practice raises many questions about the spatial and social arrangements at these mega-sites. However, one principle stands out-the potential for a wide variety of combinations of houses in groups suggests a flexible social structure that could have contributed to longer-term stability in this mega-site.

In addition to the two main circuits, the space inside the inner circuits and the space outside the outer circuits provided many more opportunities for building choices. The decision to extend geophysical prospection well outside the outer circuit has produced new insights at both Majdanetskoe and Taljanky (Burdo et al., 2012). At Nebelivka, similar house groups to those in the main circuits were constructed according to the well-known principle of building 'lines' of houses radiating inwards from the inner circuit. The length of these inner house lines ranged from $50 \mathrm{~m}$ (Area B3) to as much as $300 \mathrm{~m}$ (Area C3) (Figures 4 and 5), with as much variability in the number of constituent houses. But many of these house groupings cannot be described as 'house lines'-rather, new forms of larger house ensembles have emerged that require new descriptors. The most striking form in the inner space at Nebelivka is the so-called 'Nebelivka Square' (Area A3)-a group of both burnt and unburnt houses arranged on three sides of a square and part of the fourth, with a cluster of pits, each seemingly linked to its own house, dug in the central space (Figure 9). This ensemble is but one of a whole collection of groupings that do not appear to comprise a third, innermost circuit on the east side of the mega-site but, rather, can be fragmented into a series of ensembles with markedly different components. One of these groupings comprises three burnt houses surrounded on three sides by an E-shaped linear pit (Online Supplementary Material 3.1); another grouping, just south of 'Nebelivka Square', may be another square, with burnt houses on one side and pit lines on two more sides. We are currently unaware of the chronological dimension of these ensembles but the notion of different social groups drawing on traditional elements of design to create new spatial forms is hard to resist.

As was the case at Nebelivka, there was a lack of symmetry between the northeast and northwest parts of the settlement at Taljanky. In 2012, prospection was completed in that part of the site where Dudkin (1978) detected the highest density of buildings: two working days in perfect conditions revealed more than 600 burned houses (Figure 10). The northwestern area shows a remarkably linear house pattern, whereas the northeastern area is structured in an irregular fashion. In a general sense, there is a clear difference between the northern and southern portions of the settlement. Whereas the south 


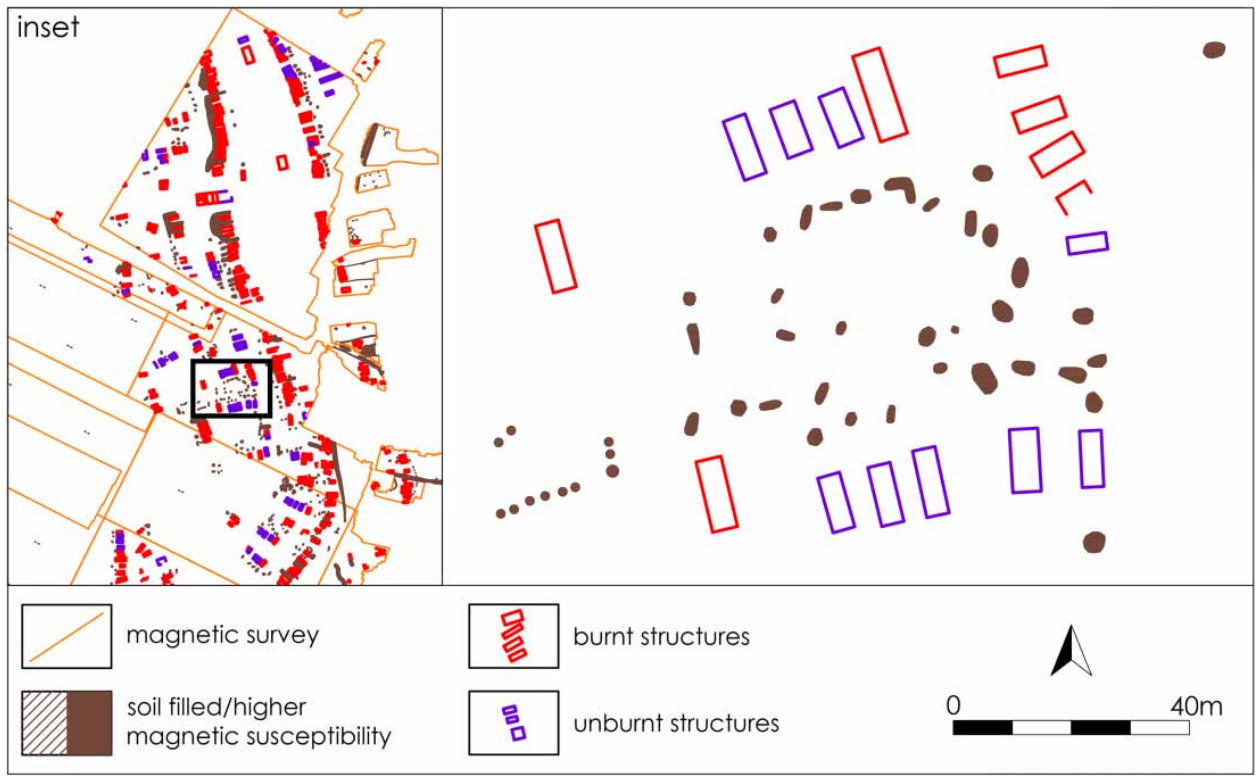

Figure 9. 'Nebelivka Square'.

Source: D. Hale, Archaeological Services

has a lower density of houses, most in radial lines, the north is characterized by more houses at a much higher density. Similar differences are visible in the central area in Maydanetske. How these imbalances were reflected in a social or political structure is unclear.

The outermost space, beyond the outer circuit, at Nebelivka has been explored in only a few areas because of local vegetation conditions. The main features appear to be linear ditches (Area 11), pit groups (Areas 9, 10 and 12), and isolated burnt houses (Areas 9, 12, and 16). Examinations of the corresponding area near Maydanetske revealed similar structures (Figure 12). The houses could have been devoted to special functions, whether as production areas (e.g. ceramic workshops or kilns), menstrual huts (Galloway, 1997), birthing huts (Beausang, 2005), places for rites of passage, homes for newcomers, or huts for social deviants.

Another new form of feature combination concerns the multiplicity of ways in which pits were dug on mega-sites. Pits were often found in groups, with two types of lines of pits in evidence. The first type shows pits in apparent association with a line of houses (outer circuit, Nebelivka Area D3: Online Supplementary Material 4.1; inner circuit, Area A3: Figure 8.2; in Taljanky most clearly in the western portion of Area A, as well as in Maydanketskoe Area A and at Dobrovody). Confirmation of the association between house and pit would suggest that the meaning of the pit was somehow implicated in the meaning of the house. It is interesting to note the general rule for matching house-and-pit lines was that the pits were dug outside the outer circuit but inside the inner circuit. However, the 2009 and 2012 plots from Nebelivka (Areas B3 and C3), as well as data from Taljanky and Maydanetske, show exceptions to this rule, with some pits dug between the main circuits (Figures 4, 5, 10, and 12). Particularly if the link between pit lines and house lines can be 


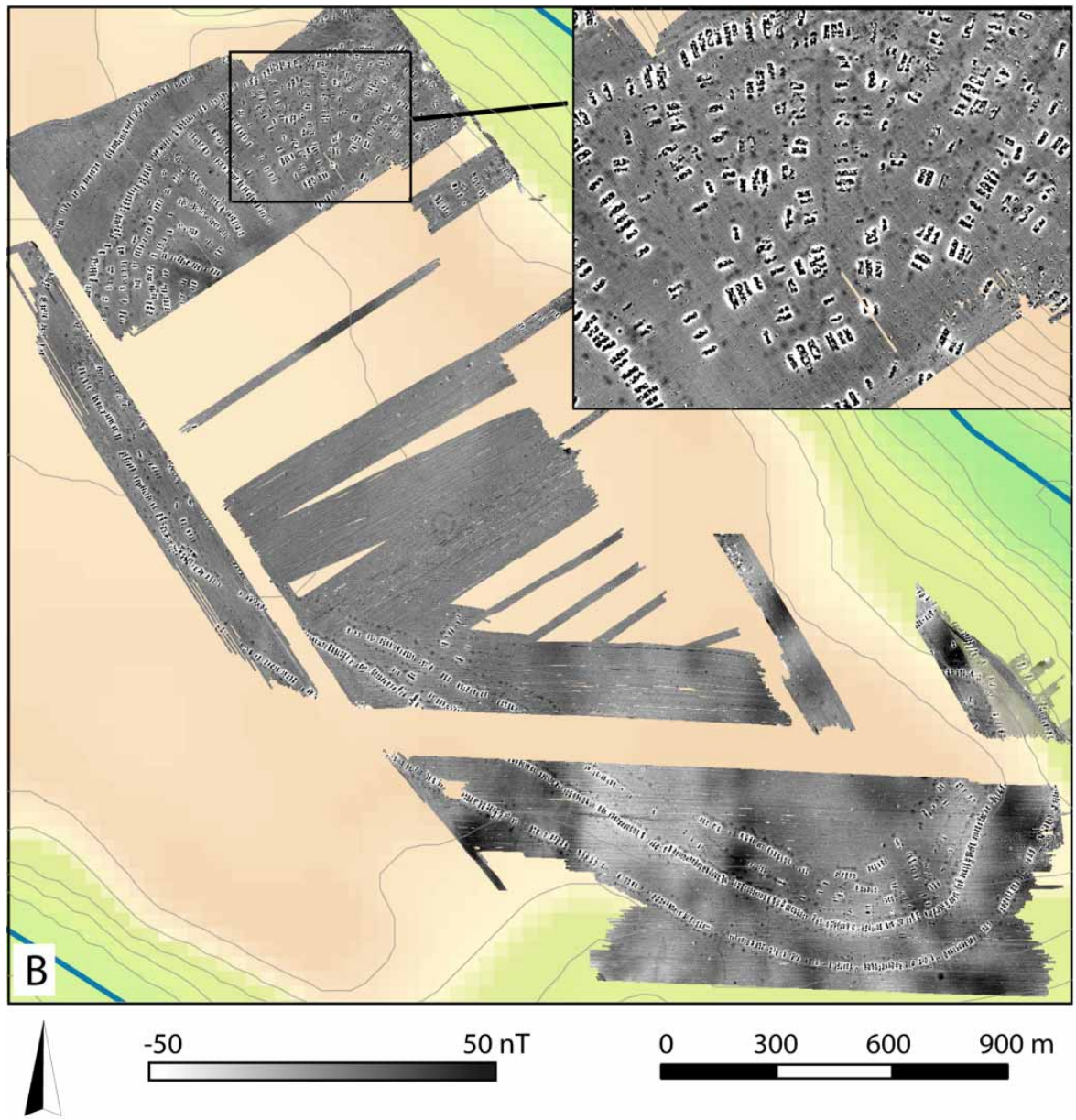

Figure 10. Taljanky. (A) Overview and location of the settlement. (B) Geomagnetic map. Source: K. Rassmann \& C. Mischka

documented, we could expect complementary discard patterns between houses and their pits. However, the second type of line of pit shows pits unrelated to any house lines (Nebelivka Areas 5, 9, and H3: Figure 6.4; Maydanetske Area B: Figures 12 and 15). If these lines of pits are not a function of differential feature preservation, they may more appropriately be described as 'pit-alignments', in which the primary meaning of the features is located in the pits themselves.

Another dimension of variability with pit lines is their length. While the majority of pit lines were dug over lengths of $100 \mathrm{~m}$ or less, several pit-lines of exceptional length were discovered at Nebelivka. The longest consists of widely spaced pits covering a length of over $700 \mathrm{~m}$ (Area H3), while shorter pit-lines whose pits were consistently associated with their own houses covered lengths of, respectively, $255 \mathrm{~m}$ (2009 Area), $185 \mathrm{~m}$ (Area A3), and $140 \mathrm{~m}$ (Area D3; Figure 4). Given the assumption that pits were dug to receive not only discarded material (both cultural and biological) but also constituted places for ritual deposition (e.g. Traian: 

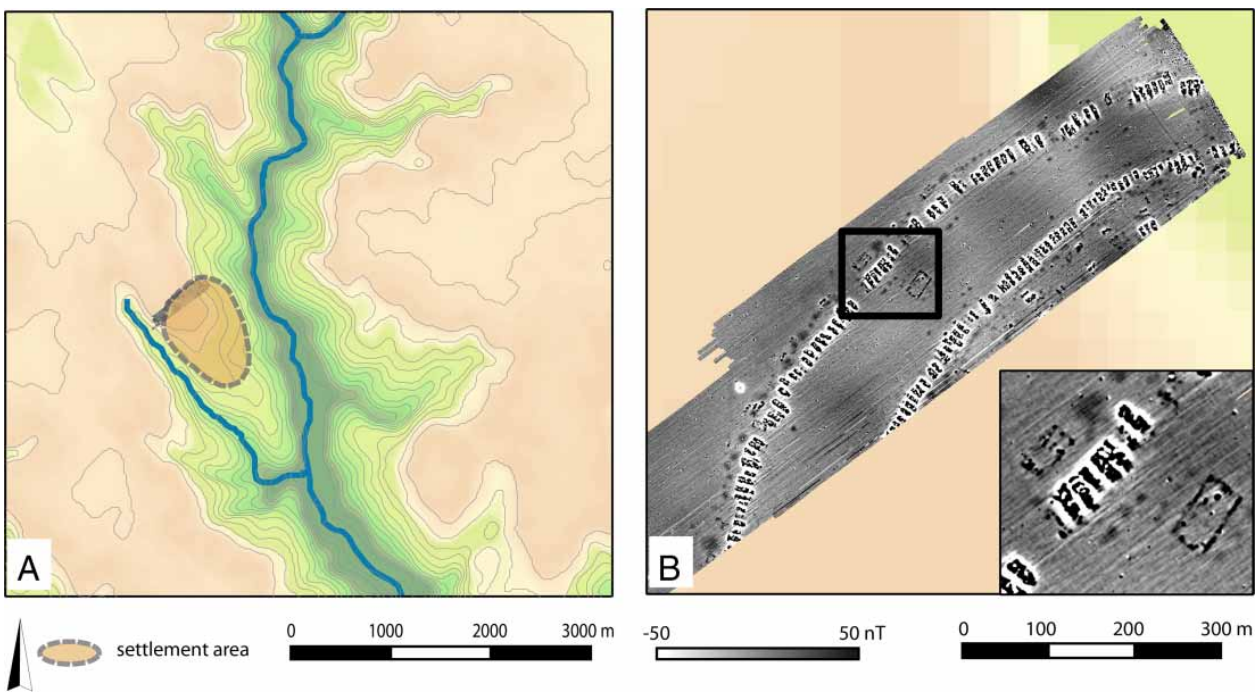

Figure 11. Dobrovody. (A) Overview and location of the settlement. (B) Geomagnetic map. Source: K. Rassmann \& C. Mischka

Dumitrescu, 1957), it may be suggested that there was a different cultural value in establishing a long but less concentrated $700 \mathrm{~m}$ pit-line in comparison to shorter but more concentrated pit-lines with frequent direct links to local houses. The obvious point is that this question requires far more targeted investigation of pits than has yet been the case on Trypillia mega-sites.

A further issue concerns the creation of bounded unbuilt space at mega-sites.
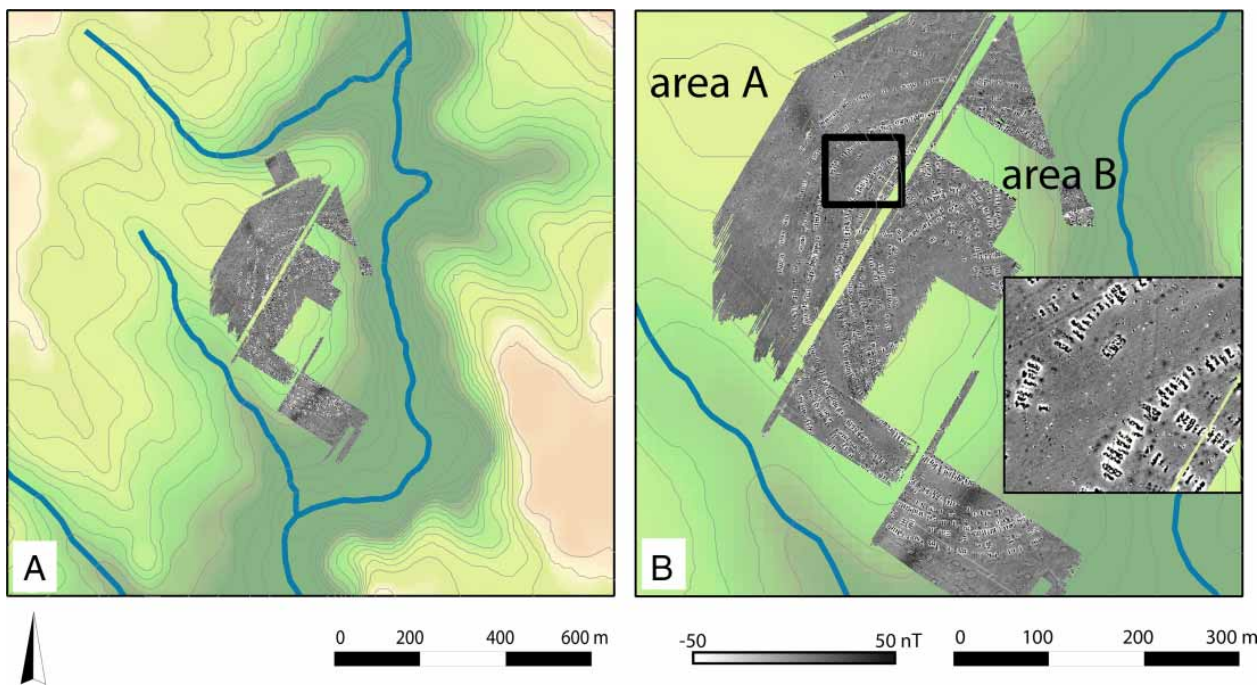

Figure 12. Maydanetske. (A) Overview and location of the settlement. (B) Geomagnetic map.

Source: K. Rassmann \& C. Mischka 
There are two examples of this practice, both well known from the earliest remote sensing. First, the limiting of building and pit-digging inside the inner circuit to a radius of $300 \mathrm{~m}$ meant that every megasite had a large open area at its heart (see plans of mega-sites in Videiko, 2012). So far, there has been limited magnetometer prospection of the supposedly empty central part of Taljanky (Figure 10) and Dobrovody (Figure 11), although a larger portion has been examined at Maydanetske (Figure 12) and the entire area of Nebelivka (Figure 4) and Apolianka (Figure 13). No excavation has yet taken place to check whether these areas are indeed empty; further research, including test-pitting, is necessary to elucidate their function. One obvious possibility is that it was a secure place for herds of animals, whether sheep, goats, cattle, pigs, or even wild horses.

A further bounded, unbuilt space was created between the two principal circuits, no matter what the size of the space depending on variable inter-circuit widths. The principle of keeping this space clear of structures and pits was largely maintained but, as we have seen, there were some exceptions. Two of the megastructures were located symmetrically between the two circuits (Nebelivka 2009 Area; Maydanetske Area A; Dobrovody), while an assortment of pits and the very occasional burnt house has been discovered in this inter-circuit area. However, the main exception to the unbuilt rule concerned the linear pit or ditch in Nebelivka Areas A3-B3 and the further complex of ditches in Areas B3-D3 (Figures 4 and 5). This exception raises the possibility that the inner circuit was standing on its own, without any outer circuit, when the ditches and linear pit were dug, thus removing the force of the exception. We do need, however, much stronger direct AMS-dated evidence before we can accept the chronological priority of the inner over the outer circuit.

This review of the recent geophysical prospection at Nebelivka, Taljanky, Majdanetskoe, and Dobrovody has demonstrated the potential of the second phase of the Trypillia methodological
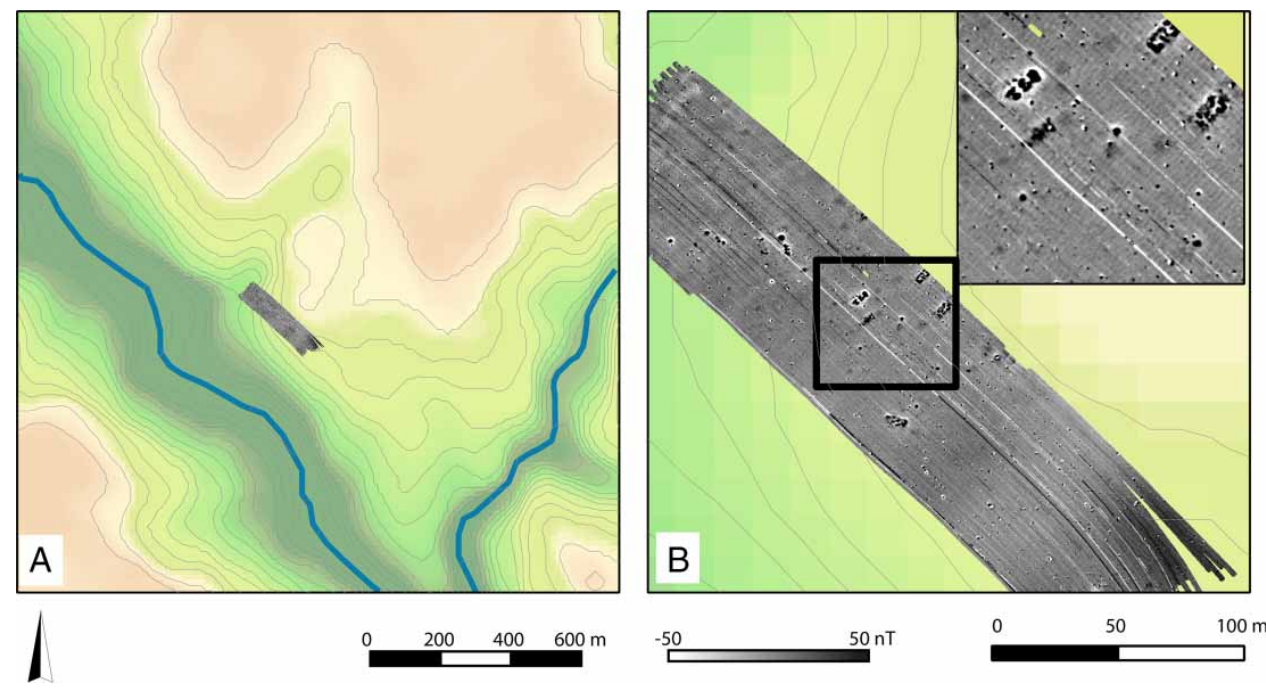

Figure 13. Apolianka. (A) Overview and location of the settlement. (B) Geomagnetic map. Source: K. Rassmann \& C. Mischka 
revolution. Not only have novel types of features and combinations of features old and new been discovered but the new plans have also improved our understanding of well-known features. We now turn to the meaning of these new discoveries, in terms of the wider issues surrounding Trypillia mega-sites. What are the implications of this process, not only for Nebelivka, but also for the other megasites under current investigation?

\section{What Does It All Mean?}

There can be no doubt that, since Childe (1929), the majority of prehistoric research in Central and Eastern Europe has been concerned with chronology, whether through typology, seriation, radiocarbon dating, calibrated radiocarbon dates or AMS dating and Bayesian statistics. This makes the case of the Trypillia mega-sites something of an exception, since attention has been divided between issues of space and relative chronology over the last forty years. In the earlier decades, the ceramic dating of a mega-site to a Trypillia phase lasting over 500 years was perhaps sufficient for local purposes but it is now claimed by some Ukrainian colleagues (especially Ryzhov, 1990, 2012) that the combination of scientific dating and pottery typology has the potential for the dating of each mega-site to a period of no more than seventy to one hundred yearsperhaps matching AMS dates for accuracy, if not precision. However, no cross-checks on this proposed pottery seriation using AMS dates have yet been made. We have already mentioned that the problems of poor sample selection for radiocarbon dating are illustrated by recent studies (Rassamakin \& Menotti, 2011; Rassamakin, 2012). It is abundantly clear that finer chronological distinctions are required to date the internal developments of a mega- site. We would put the issue more strongly: the main aims of the Trypillia methodological revolution will be subverted, and its potential achievements drastically limited, unless a sound AMSbased chronology can be developed for each mega-site. Thus, the first achievement of the new mega-site plans arising out of the second methodological revolution is to persuade researchers to take the complex question of dating such vast settlements seriously. That chronology is fundamental to future research goals will be seen in every stage of the subsequent discussion. We envisage that the combined use of further AMS dates and new spatial data will enable a rigorous testing of the Ukrainians' traditional potterybased seriation (Ryzhov, 1990, 2012) using large ceramic samples from new excavations of pits, 'linear pits', unburnt, partly burnt and burnt houses (as for the AMS testing of Neolithic ceramic seriations, see Lenneis \& Stadler, 2002; Müller, 2009).

What does it mean to say that the methodological revolution provides us with a novel, additional unit of analysisthe individual structure? Three advantages immediately accrue from this new unit of analysis - a more nuanced typology of features, better recognition of combinations of features and a sounder basis for modelling the number of features on a mega-site. In addition to the traditional types of feature recorded in early remote sensing-burnt houses at all mega-sites and possible enclosures at Taljanky-we can now identify unburnt houses, partially burnt houses, pits of several sizes, kilns, ditches, pathways, linear pits, and palaeochannels. The extension of two feature types to ten provides not only a basic alphabet for the understanding of these complex sites but also the opportunity to recognize words built up with different letters. There is no simple answer to the 
well-worn conundrum of the relationship of form to function in archaeology (Gillis, 1990; Vandkilde, 2000; Trachsel, 2005; Carver, 2009: 229-30; Trebsche, 2010). But until it is possible to differentiate a more or less complete series of the forms created by the residents of the mega-sites, how will it be possible to make progress in the interpretation, not only of the functions of each feature type-symbolic as much as utilitarian-but the functions of feature groups composed of different feature types?

At the most basic level, an accurate recognition of combinations of features depends on the prior identification of each feature in a combination of different features. One of the key areas of progress has been the differentiation of different kinds of house through geophysical prospection. The separation of completely burnt houses, houses that have been partly or half burnt and houses which appear to have been abandoned and left unburnt helps us to pose questions that would simply not have been possible from the earlier remote sensing plans. Among the most pressing is a better understanding of the taphonomy of Trypillia house construction, occupation, and destruction. There are two diametrically opposed views of the construction and destruction of a Trypillia house (see Chernovol, 2012; Korvin-Piotrovskiy et al., 2012); the development of strategies for the excavation of unburnt and partly burnt houses could hopefully provide an opportunity for resolution of this disagreement. The question of whether depositional strategies were similar for burnt, partially burnt and unburnt houses can at last be posed. And the spatial structuring of houses with these three forms of destruction processes can also be discussed.

A third potential arising from the identification of all types of mega-site feature is that, with the establishment of an AMS-based inner site sequencing, this will provide a sounder basis for modelling the number of coeval features on a megasite. In terms of a general density model, it should be feasible, as Diachenko and Menotti (2012) seek to demonstrate, to estimate the maximum possible density of structures (not people!) at Nebelivka as well as other such sites by estimating the number of structures (burnt + partially burnt + unburnt) in the area surveyed (Nebelivka: 65 ha; Maydanetske: 151 ha; Taljanky: $191 \mathrm{ha}$ ). Alternatively, taking the 'empty' core of the site into account provides a higher structural density that is perhaps unrealistic. However, a precise reconstruction of population for Nebelivka cannot be made at present because of the currently unsolved problems of house contemporaneity.

An initial estimate of the number of houses identified so far in the 65 ha geophysical prospection at Nebelivka reaches a total of nearly 350 houses, of which approximately three-quarters were burnt. This leads to an estimated maximum structural density of 5.3 structures per hectare, under the assumption that all of the houses found so far were in coeval occupation (Table 1). Given the further assumption that each house, with its mean floor area of $84 \mathrm{~m}^{2}$, was occupied by a nuclear family of eight to ten people, the estimate for a maximum population density is between forty and fifty people per hectare. The exclusion of the 'empty' core has relatively little effect on these estimates, since only 10 ha of the empty core was covered in the 2012 geophysics season. The estimated maximum structural density rises to 6.3 houses per hectare, with the estimate for a maximum population density increasing marginally to fifty to sixty persons per hectare. Perhaps surprisingly, these estimated densities are double those calculated using Kruts' (1989) size and population estimates for Taljanky and Maydanetske but, then, the 
relationship between house size and number of occupants is always debatable. A comparison of these maximum population density estimates with Fletcher's (1995) Interaction Limit of 300-600 persons per hectare for sedentary farming sites shows that, with the new data, several Trypillia mega-sites would fall well below the population density threshold, which hitherto was thought to have caused problems with crowding. This would have been true even accepting the highly improbable assumption of total simultaneous occupation of all houses in the 65 ha area of Nebelivka surveyed thus far. Rejection of this assumption may well have reduced the estimated population density to closer to the ten persons per hectare discussed by Fletcher (1995: 198). Taking into account that 'Nebelivka Square' is one of the densest areas of dwelling so far discovered at Nebelivka, a direct comparison, at the same scale, between the square and an excavated area of Old Babylonian Ur (Figures 9 and 14) shows a much higher population density in the latter than in the former-a key difference in the trajectories of these archetypal sites. Nonetheless, the size of the megasites still exceeds by far Fletcher's (1995) Communication Limit of 100 ha for sedentary farming sites, with the implication that, on such large sites, it would be hard for all or most people to keep in touch with each other for all or most of the time. After all, the distance between the southern and the northern limits of the still decidedly partial plan of Nebelivka is over $1.1 \mathrm{~km}$ or 15 minutes' walk!

Size and population estimates for the other mega-sites contrast somewhat with Nebelivka. They are based on the full geomagnetic survey of the site areas and the identification of the number of the (at least) unburned houses. Estimated at 340 ha, Taljanky includes large central areas (90-120 ha) void of building traces

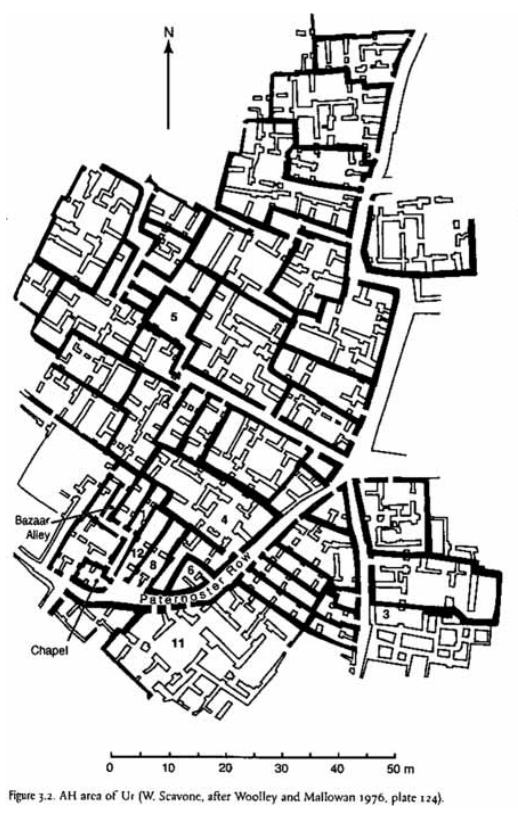

Figure 14. Excavated part of Old Babylonian Ur (cf. 'Nebelivka Square', drawn at the same scale in Fig. 9)

Source: Wooley \& Mallowan (1976): fig. pl. 124, reprinted in Keith (2003), fig. 3.2

(Figure 15). While Maydanetske (near $200 \mathrm{ha}$ ) is smaller than Taljanky (340 ha), it has a higher building density, visible in the geomagnetic plan (Figure 15). The central (unbuilt) area is also smaller, measuring only $15-20$ ha. When this is taken into account, the developed areas in Taljanky (250 ha) and Maydanetske (180 ha) are comparable. Not surprisingly, the estimated numbers of houses are nearly the same on each site. The German authors' estimates for both sites (Rassmann et al., in press) are close to those made formerly by Koščelev (2005): 1870 houses for Taljanky and 1960 houses for Maydanetske. The consequences of the numbers of houses naturally affect the population size and social structure (Figure 16). However, a more detailed sociological discussion requires an analysis of the site's internal chronology in order to determine which houses were contemporaneous. This 
Table 1. Estimation of settlement size and number of houses at selected Trypillia mega-sites

\begin{tabular}{lcccl}
\hline Site & $\begin{array}{c}\text { Size in ha } \\
\text { (area with houses) } \\
\text { uncertainty } \pm 5 \text { per cent }\end{array}$ & $\begin{array}{c}\text { Houses uncertainty } \\
\mathbf{\pm 5} \text { per cent }\end{array}$ & $\begin{array}{c}\text { Building density/ha (excluded } \\
\text { are central areas without } \\
\text { buildings }\end{array}$ & Source \\
\hline Glybochok & 115 & 700 & & $\begin{array}{l}\text { Koščelev } \\
(2005)\end{array}$ \\
Nebelivka & 250 & $?$ & & $\begin{array}{l}\text { Hale } \text { et al. } \\
(2010)\end{array}$ \\
Dobrovody & $100-120$ & 700 & & RGK/CAU \\
Olkhovets & 130 & 1850 & & Košcelev \\
Maydanetsk & $260(240)$ & 1850 & 7 & (2005) \\
Taljanky & $360(250)$ & 1750 & & RGK/CAU \\
Yatranivka & 60 & 400 & & RGK/CAU \\
& & & & Koščelev \\
& & & & \\
\hline
\end{tabular}

question was recently discussed by Diachenko and Menotti (2012). Taking these uncertainties into account within the Ukrainian-German project, it seems plausible that the population at both Taljanky and Majdanetskoe ranged between 5000 and 8000 people - a figure a third of Kruts' (1989) estimate for the former (and half as large as the population estimates for the latter) (Videiko, 1990). Analysis of former excavation data in correlation with recent prospections engendered the development of our investigation design. The first step focussed on dating samples from test pits in different circuits and house rows and was conducted during the Majdanetskoe excavations in 2013. The results of the excavation, which also aimed at the dating of the nine circuits at the site, will in future clarify the demographic models presented above.
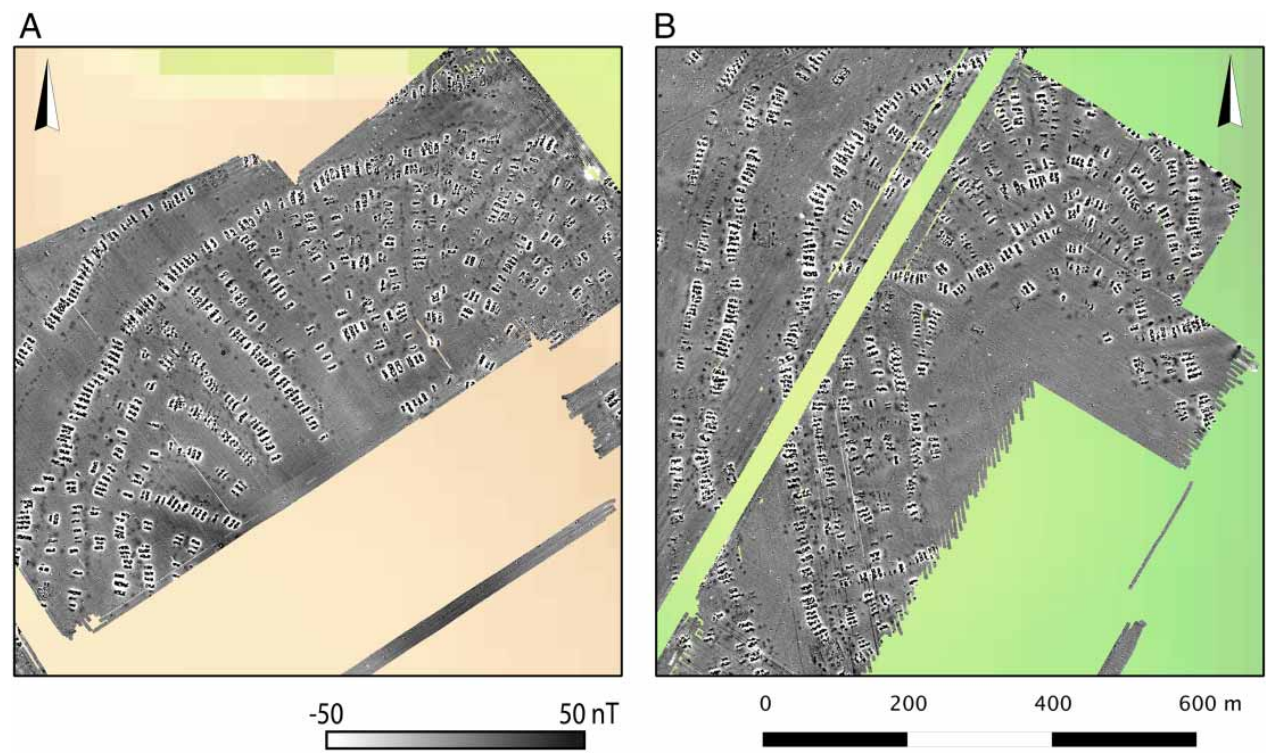

Figure 15. Central areas of Taljanky and Maydanetske: A: Taljanky, B: Maydanetske.

Source: K. Rassmann \& C. Mischka 


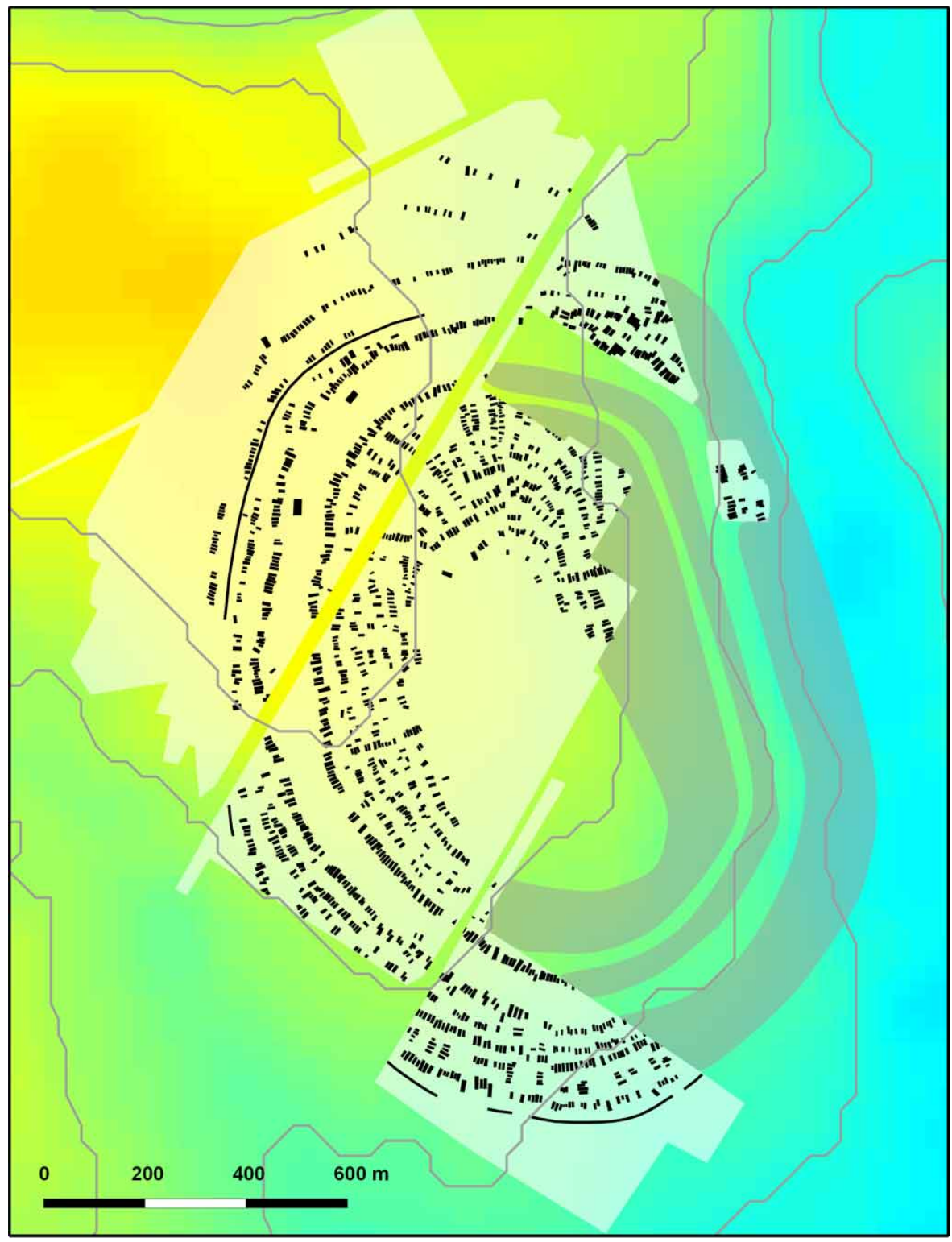

Figure 16. Maydanetske. Reconstruction of the settlement organization, based on the geomagnetic plan. Source: C. Mischka

The Structuring of Mega-Site Space

Can the new data shed any light on the second part of Fletcher's (1995) dilemma? In addition to the recognition of new feature types, the major thrust of the new geophysical investigation has been the identification of new ways of structuring the settlement space of a mega-site. We have been able to demonstrate intra-site structuring of a kind not visible when Fletcher drew his conclusions almost twenty years ago. We can recognize physical boundaries within the mega-site, 
whether palaeo-channels, pit lines, linear pits, or ditches, which can plausibly be interpreted as the interior segregation of the settlement' absent from earlier remotesensing plans (Fletcher, 1995: 198). We can also identify potential neighbourhoods from the configuration of the houses and pits. Two examples of neighbourhoods will suffice - a linear house grouping and a nucleated house grouping.

We have suggested that the pre-existing palaeo-channel structured the location of houses in the western part of Nebelivka (see above and Figure 17). In any linear pattern, the locations of individual houses are related to the twin principles of centrality and proximity. In this case, it would have been socially advantageous to hold a location of centrality in the linear pattern (e.g. houses in Groups A2 and B2), while there was tension with houses benefitting from proximity to the palaeo-channel (e.g. houses in Groups A1 and B1). Such principles-sometimes complementary, at other times opposing - would have led to different locational decisions in house groupings in other parts of the mega-site.

The second example concerns 'Nebelivka Square' (Figure 9). With an outer dimension of $80 \mathrm{~m} \times 80 \mathrm{~m}$ and an inner dimension of $50 \mathrm{~m} \times 50 \mathrm{~m}$, the square combines geometric regularity with variable composition in both houses and pits. Each of the three built-up sides appears to present a different number of houses, with maybe the largest number on the south side and the least on the north side. The pits dug in the square indicate a contrast between a line of house-related pits on the south side and an inner circle of pits, perhaps relating to their place in the centre of the square more than to the closest house. There is further ambiguity in the pits dug on the open, west side-do the pits continue to form a west-facing line? The square is one of the best examples hitherto discovered of a local neighbourhood ensemble, which manages to be both externally distinct and internally variable. Although transgressing the Greg Johnson (1982) 'scalar stress' limit of seven units in a group (see below), this group of perhaps fifteen houses could have operated as a social unit within the larger segment of the mega-site-East Central Nebelivka. In the same way, the short house lines on the inner side of the inner circuit in Area B3 could readily be construed as small neighbourhood groups, while the gaps between houses in the longer house lines in Area C3 suggest several neighbourhood groupings, structured by face-to-face contact in daily practices and probably the sharing of food, drink, labour, and material culture. The extent to which we can interpret major and minor gaps between houses in the main circuits as gaps between house groupings remains an important research question. But the issue of Communication Limits for mega-sites becomes less dramatic with the increasingly nuanced recognition of internal settlement segmentation.

A new approach of structuring possibilities and limitations of Trypillia spatial organization within the observed sites is the calculation of agent-based pedestrian movements, including the reconstruction of inter-visibility between sub-areas within the sites. To this end, the Frankfurt/Kiel team has calculated intervisibility for part of Taljanky. The result shows a clustering of three to five houses as one unit and a division between very visible areas of public space and other quarters with restricted inter-visibility (Figure 18).

\section{Discussion}

If the Trypillia methodological revolution is to transcend its technical advances, it should lead to an improved understanding 
of the general phenomenon of mega-sites, helping us to answer questions such as: (1) how was a densely packed site hierarchy sustained without the collapse of the social order; (2) could parts of the mega-site operate semi-autonomously, without a tight, top-down hierarchy; (3) how were resources organized for so many households; and (4) were there 'multiple-house' households (Doppler et al., 2010)? The new geophysical results provide the basis for starting to explore a bottom-up approach, with neighbourhoods providing an intermediary level between households and the whole settlement and 'foci' as special meeting places for people. However, the potential discovery of multiple neighbourhoods on a mega-site raises a new problem: how were these multiple units integrated? One answer concerned the interpretation of the large structures at Nebelivka, Taljanky, and Maydanetske. The excavation of the largest structure- the so-called 'mega-structure' at Nebelivka - produced conflicting interpretations of this large building $(38 \mathrm{~m} \times 20 \mathrm{~m}$ burnt, $20 \mathrm{~m} \times 20 \mathrm{~m}$ unburnt) (cf. Videiko et al., 2013; Chapman et al., in press) (see Online Supplementary Material 1 and 5). In the Ukrainian view, the mega-structure was a fully roofed two-storey $(38 \mathrm{~m} \times 20 \mathrm{~m}$ area) temple with seven altars on the ground floor, one podium and a fireplace at the second floor level, divided into three rooms with a wide corridor, and an open court $(20 \mathrm{~m} \times 20 \mathrm{~m})$ leading to a gallery. The rich cultural layer around the building, which included broken pottery, animal bones, and clay figurines, was probably connected with the rituals organized in the temple. The absence of post-holes meant that there were no burnt walls and part of the daub and finds fell from the upper storey (cf. Korvin-Piotrovskiy et al., 2012). In the British view, the mega-structure was a partially roofed public building with three

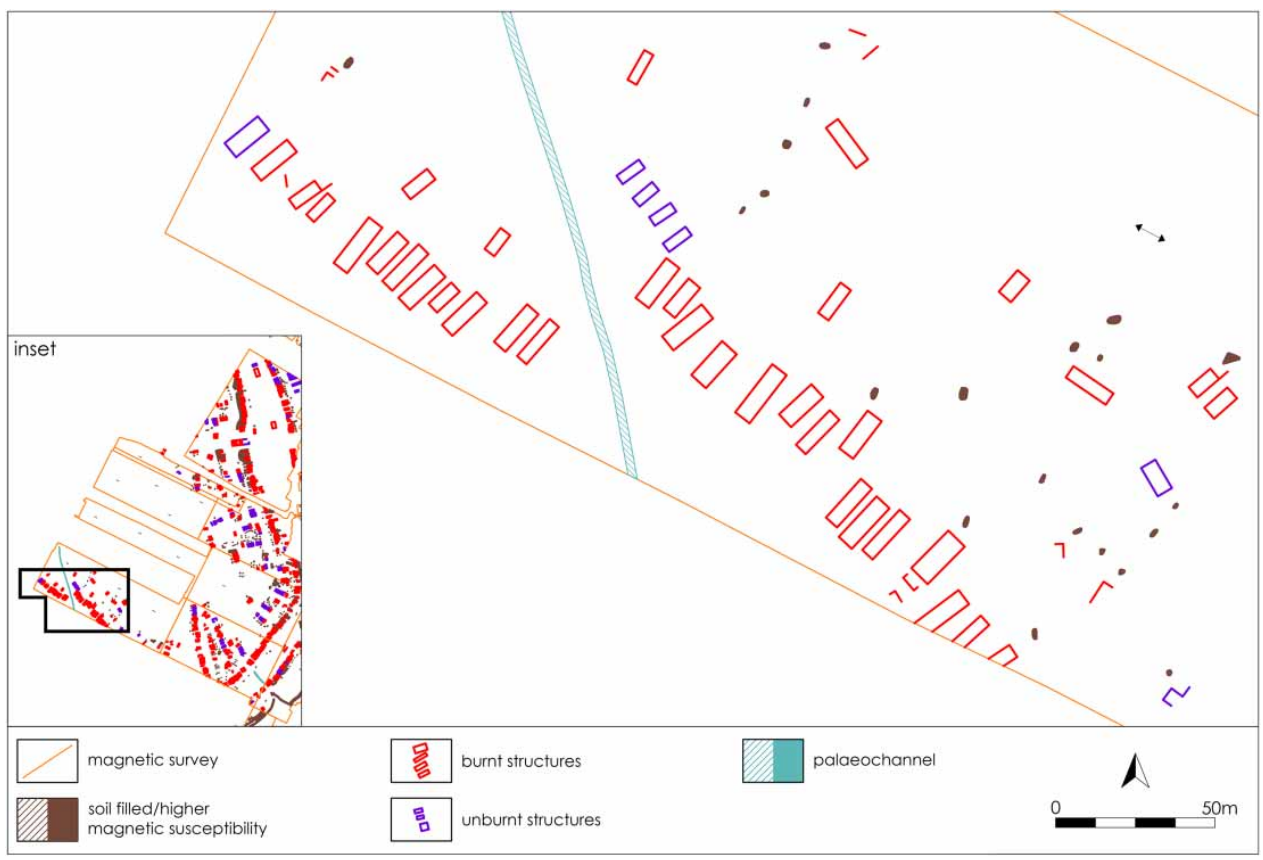

Figure 17. Western palaeo-channel, with house lines either side of the stream, Nebelivka.

Source: D. Hale, Archaeological Services 


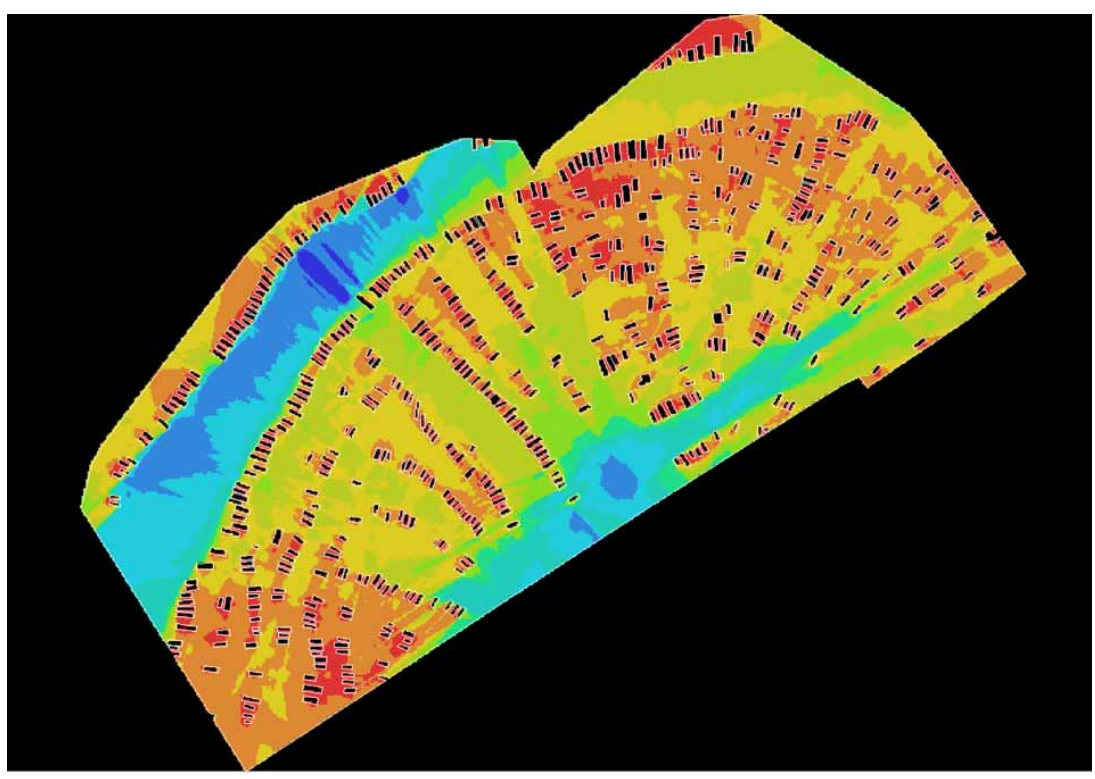

Figure 18. Taljanky. Reconstruction of inter-visibility of the north structures. Programme-deptmap 10; $6.5 \mathrm{~m}$ buffer around house centres. Communal areas with high inter-visibility are marked in blue, restricted areas in red.

Source: René Ohlrau, CAU Kiel.

rooms at the west end, an open area in the middle and a set of rooms at the east end. There were limited instances of special deposition and surprisingly few finds for such a large building. Both sides agree that architectural parallels could be made with domestic houses and that the finds were generally just as in domestic houses, with even fewer figurines and other special finds. The mega-structure seems to have constituted the 'domestic' writ large as a public building that could have co-ordinated the practices of several neighbourhood groupings but with no obvious manifestations of a hierarchical order. Videiko et al. (2013) has calculated that the labour time required to build the megastructure was twenty to thirty times the labour required for constructing a normal dwelling house (e.g. House A9, excavated in 2009: Chapman et al., in press a). However, in the mega-structure, as in most Trypillia houses, there were strong social constraints on material accumulation, whether through an ancestral ideology (e.g. Chapman, 1991) or other means.

Accepting the assumption that a network of mega-structures would play coordinating roles across each mega-site, there remains the question of population size and, as Johnson (1982) put it, 'scalar stress'. Johnson used sociological and company data to formulate the general principle that face-to-face integration of up to seven units was effective, after which a new level of decision-making was needed-in effect, in a higher-order grouping. Even if Johnson's (1982) magic number seven is extended to ten, a large number of decision-making levels would be needed on a mega-site. The extrapolation of the number of structures found in the 2009 and 2012 geophysical plots to the entire Nebelivka mega-site produces an estimated 1000 buildings. Accepting the assumption of coeval occupation, a 
pyramidal structure to avoid scalar stress would mean that ten houses would have formed a neighbourhood, with a total of 100 neighbourhoods, ten neighbourhoods would have formed a council, with a total of ten councils and the ten council leaders would have met in a supreme council. It is as hard to imagine how such a four-level hierarchy could have been maintained as it is to create a non-hierarchical solution to the logistical problems of supplying the requisite resources of water, timber, reeds, clay, flint, and salt to such a large population (Chapman, 2012). This conundrum is one of the strongest arguments for noncoeval occupation of mega-site houses. The strong constraints on material accumulation in the settlement domain, including even public buildings such as megastructures, make such hierarchical developments yet more problematic. Further exploration in the domain of kinship alliances and the formation of group values is required before we can propose an alternative to a top-down Trypillia mega-site hierarchy (Chapman, in prep.).

\section{Conclusions}

In conclusion, the second phase of the Trypillia methodological revolution is beginning to have profound influences on the way we come to understand megasites. The hitherto unsuspected variety of types of feature, not to mention combinations of features, has created a new agenda for fieldwork and, in particular, excavation, since our understanding of several new types of features is limited. One example is that, without excavation, it is hard to see how we can fully comprehend the differences between pit-lines, ditches, and linear pits and the meanings of their contents. Even more significantly, the new geophysical investigations have foregrounded the question of the similarities and differences between burnt houses, partially burnt houses and unburnt houses-another set of questions that require a new generation of fieldwork and excavation for even a partial answer. This situation has not only created a new fieldwork and excavation agenda for the next decades-it has also laid the basis for a breakthrough in how we conceptualize mega-sites. This has come about through the operationalization of new units of analysis-not only the whole settlement plan, but also the individual structure and, most importantly, the intermediate level of 'neighbourhood'. It is the last of these three units of analysis that provides the greatest challenge to Trypillia researchers, since it too requires further study to define and explain the great variability in combinations of what appears to be the same two basic features - the house and the pit.

The most intriguing new insight offered by the methodological revolution is the apparent paradox of sameness and variability. On the one hand, the settlement plan of a Trypillia mega-site would seem to depend upon the proliferation of sameness (cf. Neolithic houses in other parts of southeast Europe: Bailey, 2005; Müller, 2010; Müller-Scheessel et al., 2010a, 2010b; Müller et al., 2013; cf. prehistoric societies in general: Jones, 2012) in serial order as the key structuring principle. On the other, we have now discovered myriad ways in which Trypillia people drew on the 'same' features and created a kaleidoscopic landscape of variation in combination and re-combination in each part of several different mega-sites. This notion of intrasite variability has become even clearer with the completion of the plan of the Nebelivka mega-site (Chapman et al., 2014), and its implications in daily practice have now emerged as a crucial research question for the present and the future.

Finally, there is a real problem that the methodological revolution will be 
subverted by a lack of detailed attention to absolute chronology. The limitation of ceramic typology as a basis for the construction of fine-grained absolute chronologies is now being realized. The principal dating challenge to Trypillia researchers is the construction of AMSbased internal site sequencing that establishes chronological relationships not only between major design elements (the main circuits, the outer and inner buildings) but also between the newly recognized neighbourhoods, the burnt and unburnt houses, and the linear pits, ditches, and pit alignments. The successful production of such a complex internal sequence will underpin all of the other fruits of the new stage of Trypillia methodological revolution.

\section{Acknowledgements}

The British side: We should like to thank the Arts and Humanities Research Council for their funding for the four-year project 'Early urbanism in Europe?: the case of the Ukrainian Trypillia mega-sites' (Grant No. AH/I025867/1), as well as the National Geographic Society for their kind and much appreciated financial support for the mega-structure excavation (Grant No. 2012/211). We are very grateful to the Institute of Archaeology, Kyiv, and especially their Director, Professor P. P. Tolochko, for their support of our excavation and fieldwork at Nebelivka. Our deepest thanks go to the Deputy Governor of Kirovograd Domain, Mr. Andrei Nikolaenko, and his staff for their support and background organization. John and Bisserka should also like to thank Durham University, and especially the then Chair of Archaeology, Professor Chris Scarre, for their support of the project. Our thanks are also due to the many friends and colleagues who continue to discuss 'Eurasian urbanism' with us- first and foremost Roland Fletcher, but also Mickey Dietler, David Wengrow, Li Ping Zhou and Jerry Moore and the Hawaii 'Big Sites' group. We are also greatly indebted to Durham colleagues for their discussion of urban developments in their areas of specialization: Tony Wilkinson, Robin Coningham, Robin Skeates, Tom Moore, Richard Hingley, Rob Witcher, Anna Leone and Graham Philip. We should like to thank the villagers of Nebelivka, especially Mayor Bobko, who welcomed us to their village.

The German side: We would like to thank the Kiel Graduate School 'Human Development in Landscape' for the support of the fieldwork in Ukraine. We are thankful to the director of the Institute of Archaeology (Kyiv) Prof. P. P. Tolochko and his deputy director, Dr Alexey Korvin-Piotrovskiy, for their support of our prospections in Talianky, Maydanetske, Dobrovody and Apolianka. Roland Gaus, Patrick Mertl, Daniel Peters and Anja Sbrezsny deserve our thanks for participating in the 2011 prospection campaign, as do Rene Ohlrau and Arne Windler in 2012. We extend our gratitude to Vladimir Schebaniuk (Legedzine) for supporting prospection on the ground. The success of our prospection was granted by the patient and competent advice and problem-shooting with the MX System of Rainer Vogel and Kay Winkelmann. Many thanks to Vitaliy Rud in 2011 for technical assistance in repairing both automobiles and equipment. Our thanks go to Thomas Schulze and Tatjana Narin for their patience and fortitude in managing the administrative part of our work.

\section{REFERENCES}

Bailey, D. 2005. Beyond the Meaning of Neolithic Houses: Specific Objects and Serial Repetition. In: D. Bailey, 
A. Whittle \& V. Cummings, eds. (Un) Settling the Neolithic. Oxford: Oxbow Books, pp. 90-97.

Batóra, J., Behrens, A., Gresky, J., Ivanova, M., Rassmann, K. \& Tóth, K. 2012. The Rise and Decline of the Early Bronze Age Settlement Fidvár Near Vráble, Slovakia. In: J. Kneisel, M. Dal Corso \& W. Kirleis, eds. Collapse or Continuity? Environment and Development of Bronze Age Human Landscapes. Proceedings of the Workshop 'Socio-Environmental Dynamics Over the Last 12,000 Years: The Creation of Landscapes 2', March 2011. Bonn: Rudolf Habelt, pp. 111-30.

Beausang, E. 2005. Children and Mothering in Archaeology. Gothenburg: University of Gothenburg Department of Archaeology.

Bibikov, S.N. 1965. Hozyaisvenno-ekonomicheskyii kompleks razvitogo Tripol'ya. (Opit izuch. pervobit. ekonomiki). Sovetskaya Arheologiya, 1:48-62.

Burdo, N., Videiko, M., Chabaniuk, V.V., Rassmann, K., Gauss, R., Lueth, F. \& Peters, D. 2012. Large-Scale Geomagnetic Prospections at Majdanetskoe, Using of New Equipment to Understanding the Tripolye Megasite Phenomenon. Stratum Plus, 2012(2):265-86.

Carver, M. 2009. Archaeological Investigation. London: Routledge.

Chapman, J. 1991. The Creation of Social Arenas in the Neolithic and Copper Age of South East Europe: The Case of Varna. In: P. Garwood, P. Jennings, R. Skeates \& J. Toms, eds. Sacred and Profane. Oxford Committee for Archaeology Monograph 32. Oxford: Oxbow, pp. 152-71.

Chapman, J. 2012. From the Varna Cemetery to the Tripolye Mega-Sites: New Arenas of Power. In: T.L. Kienlin \& A. Zimmermann, eds. Beyond Elites. Alternatives to Hierarchical Systems in Modeling Social Formations. Bonn: Rudolf Habelt, pp. 225-42.

Chapman, J. 2014. The Tripillia Mega-Sites Project. Early urbanism in prehistoric Europe?: The Case of the Tripillia Mega-Sites [online] [accessed 9 April 2014]. Available at: <http://community. dur.ac.uk/j.c.chapman/tripillia/>.

Chapman, J. in preparation. Hierarchies, Heterarchies or Kinship Alliances? Social Structures at Trypillia Mega-Sites.
Chapman, J., Videiko, M., Gaydarska, B., Burdo, N., Hale, D., Villis, R., Swann, N., Thomas, N., Edwards, P., Blair, A., Hayes, A., Nebbia, M. \& Rud, V. 2014. The Planning of the Earliest European Proto-Towns: A New Geophysical Plan of the Trypillia Mega-Site of Nebelivka, Kirovograd Domain, Ukraine. Antiquity Gallery. Available at: <http://antiquity.ac. uk.ezphost.dur.ac.uk/projgall/chapman339/>.

Chapman, J., Videiko, M. Yu, Gaydarska, B., Burdo, N. \& Hale, D. in press. An Answer to Roland Fletcher's Conundrum?: Preliminary Report on the Excavation of a Trypillia Mega-Structure at Nebelivka, Ukraine. In: A. Diachenko, ed. V.A. Kruts Festschrift.

Chapman, J., Videiko, M., Gaydarska, B., Burdo, N. \& Hale, D. in press a. Nebelivka: In Search of the History and Meaning of a Trypillia Copper Age Mega-Site. In: S. Hansen \& P. Raczky, eds. Chronologies, Lithics and Metals. Late Neolithic and Copper Age in the Eastern Part of the Carpathian Basin and in the Balkans. Berlin: Budapest.

Chernovol, D. 2012. Houses of the Tomashovskaya Local Group. In: F. Menotti \& A.G. Korvin-Piotrovskiy, eds. The Tripolye Culture Giant-Settlements in Ukraine. Formation, Development and Decline. Oxford: Oxbow Books, pp. 182209.

Childe, V.G. 1928. The Most Ancient East: The Oriental Prelude to European Prehistory. London: Kegan Paul, Trench, Trubner \& Co.

Childe, V.G. 1929. The Danube in Prebistory. Oxford: Clarendon Press.

Childe, V.G. 1945. Review of 'Tripi'l'ska kultura', Akademia Nauk Ukrainian S.S.R., Institut Arkheologiy, Kiev, 1940. Antiquity, 19:203-06.

Claessen, H.J.M. \& van der Velde, P. 1991. Early State Economics. New Brunswick: Transaction.

Diachenko, A. \& Menotti, F. 2012. The Gravity Model: Monitoring the Formation and Development of the Tripolye Culture Giant-Settlements in Ukraine. Journal of Archaeological Science, 39:2810-17.

Doppler, T., Pichler, S., Jacomet, S., Schibler, J. \& Röder, B. 2010. Archäobiologie als 
sozialgeschichtliche Informationsquelle: ein bisland vernachlässigtes Forschungspotential. In: E. Classen, T. Doppler \& B. Ramminger, eds. Familie Verwandtschaft-Sozialstrukturen. Sozialarchäologische Forschungen zu neolithischen Befunden. Kerpen-Loogh: Welt \& Erde, pp. 119-39.

Dudkin, V.P. 1978. Geofizicheskaya razvedka krupnih tripol'skih poselenii. In: V.F. Genining, ed. Ispol'zovanie metodov estestvennih nauk v arheologii. Kyiv: Naukova Dumka, pp. 35-45.

Dudkin, V.P. \& Videiko, M.Y. 1998. Arheometrinchni doslidzhennya tripil'skoi tsivilizatsii. Arheometriya i oborona istorikokul'turnoi spadshtini. Visnikin-tupam.ohoron. dosl., 2:7-28.

Dudkin, V.P. \& Videiko, M.Y. 2004. Planuvanna poselen' trypil's'koi kul'tury. In: M.Y. Videiko, ed. Encyclopaedia Tripil's'koi cyvilizacii, Vol. 1. Kyiv: Ukrpoligrafmedia, pp. 303-14.

Dumitrescu, H. 1957. Découvertes concernant un rite funéraire dans l'aire de la civilisation de la céramique de type Cucuteni-Tripolie. Dacia, 1:97-116.

Dumitrescu, V., Dumitrescu, H., Petrescu-Dîmbovița, M. \& Gostar, N. 1954. Hăbăşeşti. Monografie arheologică. Bucureşti: Institutul de Arheologiă al Academiei RPR.

Ellis, L. 1984. The Cucuteni-Tripolye Culture: Study in Technology and the Origins of Complex Society. British Archaeological Reports International Series 217. Oxford: Archaeopress.

Fletcher, R. 1995. The Limits to Settlement Growth. Cambridge: Cambridge University Press.

Galloway, P. 1997. Where Have All the Menstrual Huts Gone? The Invisibility of Menstrual Seclusion in the Late Prehistoric Southeast. In: C. Claassen \& R. Joyce, eds. Women in Prehistory: North America and Mesoamerica. Philadelphia: University of Pennsylvania Press, pp. 47-62.

Gillis, C. 1990. Minoan Conical Cups. Form, Function and Significance. Studies in Mediterranean Archaeology 89. Gothenburg: Paul Åstroms Förlag.

Gimbutas, M. 1974. The Gods and Goddesses of Old Europe, 7000-3500 BC: Myths, Legends and Cult Images. London: Thames \& Hudson.
Hale, D., Chapman, J., Swann, N., Videiko, M. \& Villis, R. 2010. Early Urbanism in Europe? Geophysical Survey at Nebelivka, Ukraine. In: P. Linford \& L. Martin, eds. Recent Work in Archaeological Geophysics. The Geological Society. Abstracts. London: Geological Society, pp. 35-36.

Johnson, G.A. 1982. Organizational Structure and Scalar Stress. In: C.R. Renfrew, M. Rowlands \& B.A. Segraves, eds. Theory and Explanation in Archaeology: The Southampton Conference. London: Academic Press, pp. 389-421.

Jones, A.M. 2012. Prehistoric Materialities. Cambridge: Cambridge University Press.

Keith, K. 2003. The Spatial Patterns of Everyday Life in Old Babylonian Neighbourhoods. In: M.L. Smith, ed. The Social Construction of Ancient Cities. Washington: Smithsonian Books, pp. 5680.

Korvin-Piotrovskiy, A., Chabanyuk, V. \& Shatilo, L. 2012. Tripolian House Construction: Conceptions and Experiments. In: F. Menotti \& A.G. Korvin-Piotrovskiy, eds. The Tripolye Culture Giant-Settlements in Ukraine. Formation, Development and Decline. Oxford: Oxbow Books, pp. 21029.

Koščelev, I.I. 2005. Monuments of the Tripolian Culture in the Light of Geomagnetic Prospection. Kyiv: Biblioteka V. I. Vernadskogo.

Kruts, V. 1989. K istorii naseleniya tripol'skoi kul'turi v mezdurechie Yuzhnovo Buga i Dnepra. Pervobitnaya Arehologiya, 1:117-31.

Kruts, V., Korvin-Piotrovskiy, A., Ryzhov, S., Buzyan, G., Ovchinnikov, E., Chernovol, D. \& Chabaniuk, V. 2005. Issledovanie poselenii-gigantov Tripolskoi kulturi, 2002$2004 \mathrm{gg}$. Kyiv: Institute of Archaeology.

Kruts, V.A. 2012. Giant-Settlements of Tripolye Culture. In: F. Menotti \& A. Korvin-Piotrovskiy, eds. The Tripolye Culture Giant-Settlements in Ukraine. Formation, Development and Decline. Oxford: Oxbow Books, pp. 70-78.

Kruts, V.A., Korvin-Piotrovskiy, A.G., Peters, D. \& Rassmann, K. 2012. Taljaniki Reloaded: Geomagnetic Prospection Three Decades after V. P. Dudkin's Work. In: V.A. Kruts \& A. G. Korvin-Piotrovskiy, eds. Settlement Giants of the Tripolian Culture. 
Investigation 2011. Kiev: Korvin-Press, pp. 60-85.

Kruts, V.A., Korvin-Piotrovskiy, A.G. \& Ryzhov, S. 2001. Tripol'skoe poseleniegigant Taljaniki. Issledovaniya 2001 S. Kyiv: Korvin-Press.

Lenneis, E. \& Stadler, P. 2002. 14C-Daten und Seriation altbandkeramisher Inventare. Festschrift für Marie Zápotocká. Archeologické Rozhledy, 54:191201.

Mantu, C.-M., Dumitroaia, G. \& Tsaravopoulous, A. eds. 1997. Cucuteni The Last Great Chalcolithic Civilization of Europe. Bucharest: Athena Publishing \& Printing House.

Marinescu-Bîlcu, S. 2000. Dwellings, Pits. In: S. Marinescu-Bîlcu \& A. Bolomey, eds. Drăguşeni. A Cucuteni Community. Bucureşti: Editura Enciclopedică, pp. 4248.

Masson, V.M. 1980. Dinamika razvitya tripolskogo obshtestva $\mathrm{v}$ svete paleodemograficheskih otsenok. In: I. I. Artemenko, ed. Pervobitnaya arkheologiya. Poiski $i$ nahodki. Kiev: Naukova Dumka, pp. 204-12.

Monah, D. 2003. A Ghost is Haunting Europe: The Neolithic Proto-Cities. In: V.A. Kruts \& A.G. Korvin-Piotrovskiy, eds. Settlement Giants of the Tripolian Culture. Investigation 2011. Kiev: Korvin-Press, pp. 239-43.

Müller, J. 2009. Dating the Neolithic: Methodological Premises and Absolute Chronology. Radiocarbon, 51: 721-36.

Müller, J. 2010. Dorfanlagen, Siedlungssysteme Die europäische Perspektive: Südosteuropa und Mitteleuropa. In: C. Lichter, ed. Aufbruch in eine neue Zeit: Europas Mitte um 4000 v. Chr. Karlsruhe: Theiss, pp. 250-57.

Müller, J. 2014. Forschung des Institutes zu Tripolje [online] [accessed 9 April 2014]. Available at: <http://www.ufg.uni-kiel.de/ index.php/?option=com_content\&view=ar ticle\&id=198/ > .

Müller, J., Rassmann, K. \& Hofmann, R. eds. 2013. Okoliste - Untersuchungen einer spätneolithischen Siedlungskammer in Zentralbosnien. Neolitbikum und Chalkolithikum in Zentralbosnien. Bonn: Habelt.

Müller-Scheessel, N., Müller, J. \& Hofmann, R. 2010a. Entwicklung und Struktur des spätneolithischen Tells von Okolište (Bosnien-Herzegowina) unter architektursoziologischen Gesichtspunkten. In: P. Trebsche, N. Müller-Scheessel \& S. Reinhold, eds. Der gebaute Raum : Bausteine einer Architektursoziologie vormoderner Gesellschaften. Münster: Waxmann, pp. 171-92.

Müller-Scheessel, N., Müller, J. \& Hofmann, R. 2010b. The Socio-Political Development of the Late Neolithic Settlement of Okoliste/Bosnia-Hercegowina: Devolution by Transhumance? In: J. Müller, ed. Landscapes and Human Development. The Contribution of European Archaeology. Proceedings of the International Workshop Socio-Environmental Dynamics over the Last 12,000 Years: The Creation of Landscapes (1st-4th April 2009)'. Bonn: Habelt, pp. 181-91.

Narr, K.J. ed. 1975. Handbuch der Urgeschichte. Zweiter Band: Jüngere Steinzeit und Steinkupferzeit. Bern: Francke Verlag.

Passek, T.S. 1940. Tripil'ska kul'tura. Kyiv: Vidavnisttvo Akademii Nauk URSR.

Petrov, V. 1992(1947). Pohoddzhennya ukrainskogo narodu. Kyiv: Feniks.

Rassamakin, Y. 2012. Absolute Chronology of Ukrainian Tripolye Settlements. In: F. Menotti \& A. Korvin-Piotrovskiy, eds. The Tripolye Culture Giant-Settlements in Ukraine. Formation, Development and Decline. Oxford: Oxbow Books, pp. 19-69.

Rassamakin, Y. \& Menotti, F. 2011. Chronological Development of the Tripolye Culture Giant-Settlement of Talianki (Ukraine): 14C Dating vs. Pottery Typology. Radiocarbon, 53(4): 645-57.

Rassmann, K., Mischka, C. \& Müller, J. in press. High Precision Trypillia Settlement Plans, Demographic Estimations and Settlement Organization. Journal of Neolithic Archaeology, 16.

Ryzhov, S. 1990. Mikrohronologiya poseleniya u s. Taljanky. In: V.G. Zbenovich, ed. Rannezemledelcheskie poseleniya- giganti tripol'skoi kulturi na Ukraine. Tez. dokl. I polevogo seminara. Kyiv: Dumka, pp. 8390.

Ryzhov, S. 2012. Relative Chronology of the Giant-Settlement Period BII-CI. In: F. Menotti \& A. Korvin-Piotrovskiy, eds. The Tripolye Culture Giant-Settlements in 
Ukraine. Formation, Development and Decline. Oxford: Oxbow Books, pp. 79115.

Shishkin, K.V. 1973. Z praktiki deshifruvannya aero-fotoznimkiv u arheologichnih tsiliyah. Arheologiya, 10:32-41.

Shishkin, K.V. 1985. Planuvannya tripilskih poselen za danimi aerofotoziomki. Arbeologiya, 52:72-77.

Shmaglij, N.M. 1980. Krupnie tripol'skie poseleniya $\mathrm{v}$ mezdurechie Dnepra i Yuzhnogo Buga. In: I.I. Artamenko, ed. Pervobitnaya arehologiya - poisk $i$ nahodki. Kyiv: Naukova Dumka, pp. 198-203.

Shmaglij, N.M. \& Videiko, M. Yu. 1987. Svyatilishta i kul'tovie mesta na krupnih tripol'skih poseleniyah. Religioznie predstavleniya $\mathrm{V}$ pervobitnom obshtestve. Doctoral thesis, Moskva University.

Shmaglij, N.M. \& Videiko, M. Yu. 1990. Mikrohronologiya poseleniya Majdenetskoe. In: V.G. Zbenovich, ed. Rannezemledelcheskie poseleniya- giganti tripol'skoi kulturi na Ukraine. Tez. dokl. I polevogo seminara. Kyiv: Naukova Dumka, pp. 91-94.

Shmaglij, N.M. \& Videiko, M. Yu. 2002-3. Majdenetskoe - tripol'skyii protogorod. Stratum Plus, 2:44-136.

Shmaglij, N.M., Dudkin, V.P. \& Zinakovskyii, K.V. 1973. Pro kompleksne vivchennya tripil'skih poselen. Arheologiya, 10:23-31.

Trachsel, M. 2005. Feuchtbodensiedlungen als sozialgeschichtliche Quelle. Ergänzungen und Perspektiven nach 150 Jahren Forschung. In: P. Dalla Casa \& M. Trachsel, eds. WES'04 Wetland Economies and Societies. Proceedings of the International Conference in Zurich, 10-13 March 2004. Zürich: Chronos, pp. 299326.

Trebsche, P. 2010. Architektursoziologie und Prähistorische Archäologie: Methodische Überlegungen und Aussagepotenzial. In: P. Trebsche, N. Müller-Scheeßel \& S. Reihold, eds. Der Gebaute Raum: Bausteine einer Architektursoziologie vormoderner Gesellschaften. Münster: Waxmann, pp. 143-70.

Tsvek, E. 2004. Vesely Kut. In: M. Yu. Videiko, S. Lyashko \& N. Burdo, eds. Encyclopaedia Tripil's'koi cyvilizacii, Vol. 2. Kyiv: Ukrpoligrafmedia, pp. 85.
Vandkilde, H. 2000. Material Culture and Scandinavian Archaeology: A Review of the Concepts of Form, Function and Context. In: D. Olausson \& H. Vandkilde, eds. Form, Function and Context: Material Studies in Scandinavian Archaeology. Acta Archaeologia Lundensia Series In 80, No. 31. Stockholm: Almqvist \& Wiksell International, pp. 3-49.

Videiko, M. Yu. 1990. Zhilishtno-hozyastvenie kompleksi Majdenetskogo i voprosi ih interpretatsii. In: V.G. Zbenovich, ed. Rannezemledelcheskie poseleniya- giganti tripol'skoi kulturi na Ukraine. Tez. dokl. I polerogo seminara. Kyiv: Naukova Dumka, pp. 115-20.

Videiko, M. Yu. 2004. Sporudi tripil'skoi kul'turi. In: M. Yu. Videiko, ed. Encyclopaedia Tripil's'koi cyvilizacii, Vol. 1. Kyiv: Ukrpoligrafmedia, pp. 315-41.

Videiko, M. Yu. 2007. Contours and Contents of the Ghost: Trypillia Culture Proto-Cities. Memoria Antiquitatis, 24:251-76.

Videiko, M. Yu. 2012. Comprehensive Study of the Large Settlements of the Tripolye Culture: 1971-2011. Stratum Plus, 2012 (2):225-63.

Videiko, M. Yu. 2013. Kompleksno izuchenie krupnih poselenii tripol'skoi kul'turi. Saarbrucken: Lambert Academic Publishing.

Videiko, M. Yu., Chapman, J., Gaydarska, B., Burdo, N., Ovchinnikov, E., Pashkevych, G. \& Shevchenko, N. 2013. Investigations of the Mega-Structure at the Trypillia Culture Settlement Near Nebelivka in 2012. Tyragetia, Seria Noua 7(1):97-123.

Wooley, L. \& Mallowan, M. 1976. The Old Babylonian Period. London: British Museum Publications.

Zbenovich, V. 1989. The Early Stage of Tripolye Culture on Ukraine's Territory. Kiev: Naukova Dumka.

\section{Biographical Notes}

John Chapman is Professor of European Prehistory at Durham University. He has pioneered the field of deliberate fragmentation in archaeology and co-directed major excavation and fieldwork projects in Croatia and Hungary. In his current 
AHRC-funded project, he is investigating the origins, growth and decline of Trypillia mega-sites in Ukraine.

Address: Department of Archaeology, Durham University, South Road, Durham, DH1 3LE, UK [email: j.c. chapman@dur.ac.uk].

Mikhail Videiko is a senior researcher at the Institute of Archaeology NAS of Ukraine. He has researched mega-sites in Ukraine, including geophysical surveys and excavations, since 1972.

Address: 12 Geroiv Stalingrada Ave., 04210 Kyiv-210, Ukraine [email: wideiko@gmail.com].

Duncan Hale is a Senior Archaeologist within Archaeological Services at Durham University, where he manages the geophysical survey service. He has worked in archaeological geophysics for over 20 years, throughout the UK and abroad, for both research and commercial projects.

Address: Department of Archaeology, Durham University, South Road, Durham, DH1 3LE, UK [email: d.n.hale@dur.ac. uk].

Bisserka Gaydarska is currently the PostDoctoral Research Associate for the AHRC-funded Trypillia Project. She completed her $\mathrm{PhD}$ on GIS and landscape archaeology of southeast Bulgaria at Durham University and has collaborated with John Chapman on fragmentation research. She has also written about gender archaeology and the history of archaeology.
Durham, DH1 3LE, UK [email: b_gay darska@yahoo.co.uk].

Natalia Burdo is a senior researcher at the Institute of Archaeology NAS of Ukraine. She has researched the mega-sites in Ukraine, including excavations at Maydanetske and Nebelivka since 1972.

Address: 12 Geroiv Stalingrada Ave., 04210 Kyiv-210, Ukraine [email: nbburdo@gmail.com].

Knut Rassmann is a researcher associated with the Romano-Germanic Commission of the German Archaeological Institute in Frankfurt am Main. His special interests are in the prehistory of Central, Southeast and Eastern Europe. He has pioneered large scale geophysical surveys and excavations on Neolithic, Copper and Early Bronze Age sites in Central and Southeast Europe.

Address: Römisch-Germanische Kommission, Deutsches Archäologisches Institut, Palmengartenstr. 10-12, 60325 Frankfurt am Main, Germany [email: knut.rass mann@dainst.de].

Carsten Mischka is research fellow and lecturer at the Institute of Pre- and Protohistoric Archaeology at CAU Kiel. He has pioneered large-scale geophysical surveys on Neolithic sites and the Roman Limes and is engaged in research on Neolithic settlement structures.

Address: Institut für Ur- und Frühgeschichte, Johanna-Mestorf-Str. 2-6 D-24098 Kiel, Germany [email: carsten_mischka@gmx.de].

Johannes Müller is Professor and Director at the Institute of Pre-and Protohistoric

Address: Department of Archaeology, Durham University, South Road, 
Archaeology of Christian-Albrechts-University Kiel. He has pioneered the field of social space in prehistoric landscapes and co-directed major excavation and fieldwork projects in Central and Southeast Europe. In the DFG-funded GSHDL, he is analyzing Tripolje structures.

Address: Institut für Ur- und Frühgeschichte, Johanna-Mestorf-Str. 2-6 D24098 Kiel, Germany [email: johannes. mueller@ufg.uni-kiel.de].

Aleksey Korvin-Piotrovskiy is a senior researcher at the Institute of Archaeology NAS of Ukraine, where he is Scientific
Secretary. He has researched mega-sites (Taljanky, Dobrovody and Kosenivka) in Ukraine since 1981.

Address: 12 Geroiv Stalingrada Ave., 04210 Kyiv-210, Ukraine.

Volodymyir Kruts is a senior researcher at the Institute of Archaeology NAS of Ukraine and Vice-Director of the 'Trypilska kultura' Reserve at Legedzyne. He has researched the mega-site at Taljanky since 1981.

Address: 12 Geroiv Stalingrada Ave., 04210 Kyiv-210, Ukraine.

\section{Deuxième phase de la révolution méthodologique du méga-site de Trypillia: un nouveau programme de recherche}

La première phase de la révolution méthodologique sur les méga-sites de Trypillia commençait en 1971 avec la photographie aérienne, la prospection magnétique et les fouilles archéologiques des immenses surfaces habitées, s'étendant sur des centaines de hectares et appartenant à la culture de Trypillia en Ukraine. Depuis 2009 nous avons créé une seconde phase de la révolution méthodologique des études des méga-sites de Trypillia, qui a permis des progrès plus significatifs dans notre compréhension des ces grands sites que tous les autres projets de recherche des trois dernières décennies; aussi grâce à la participation d'équipes ukraino-étrangères conjointes. Cet article présente les principaux aspects de la deuxième phase, en utilisant des exemples du projet anglo-ukrainien 'Débuts de l'urbanisme en Europe prébistorique: les méga-sites de Tryptillia' basé à Nebelivka (ou 'Nebilivka') ainsi que du projet ukrainoallemand 'Economie, démographie et espace social des méga-sites de Trypillia', basé à Taljanky ('Talianki'), Maydanetske ('Maidanetske') et Dobrovody, de même que sur le site plus petit d'Apolianka. Translation by Isabelle Gerges.

Mots-clés: méga-site, Trypillia, méthode archéologique, village, maisons

\section{Die zweite Phase des methodologischen Revolution der Tripolje-Großsiedlungen: Eine neue Forschungsagenda}

Seit 1971 wurden unter dem Einsatz der Luftbildarchäologie, von geomagnetischen Prospektionen und archäologischen Grabungen ukrainische und moldavische Tripolje-Großsiedlungen, deren Größe von mehreren hundert Hektar eine Herausforderung für jede Form der Archäologie darstellt, entschlüsselt. Können wir diesen ersten umfangreichen Einsatz moderner Methoden als erste Phase einer ,Revolution' in der Erforschung besagter Strukturen bezeichnen, erfolgt seit 2009 - teils Dank gemeinsamer ukrainisch-ausländischer Teams - in einer zweiten Phase des Einsatzes modernster Methoden ein nochmals erheblicher Wissensfortschritt. Erste Ergebnisse des anglo-ukrainischen Projektes, Früher Urbanismus im 
präbistorischen Europa: die Tripolje-Großsiedlungen', das in Nebelivka tätig ist, und des ukrainischdeutschen Projekts ,Wirtschaft, Demographie und soziale Orginsation der Tripolje-Großsiedlungen', das in Majdanetskoe, Taljanky und Dobrovody sowie auf dem kleineren Fundplatz. Apoljanka tätig ist, verdeutlichen dies. Translation by Heiner Schwarzberg and Johannes Müller.

Stichworte: Großsiedlung, Tripolje, archäologische Methodik, Siedlung, Häuser 